\title{
Long distance dispersal and pseudo-cryptic species in Gastrotricha: first description of a new species (Chaetonotida, Chaetonotidae, Polymerurus) from an oceanic island with volcanic rocks
}

\author{
Letícia MAGPALI $^{1}$, Danilo R.P. MACHADO ${ }^{2}$, Thiago Q. ARAÚJO ${ }^{3}$ \& \\ André R.S. GARRAFFONI ${ }^{4, *}$ \\ 1,2,3,4 Laboratory of Evolutionary Meiofaunal Organisms, Department of Animal Biology, Institute of \\ Biology, University of Campinas, Monteiro Lobato, 255, CEP 13083-862, Campinas, SP, Brazil. \\ *Corresponding author: arsg@unicamp.br \\ 1Email: leticiamagpali@gmail.com \\ 2Email: daniloreali@gmail.com \\ ${ }^{3}$ Email: araujotq@gmail.com

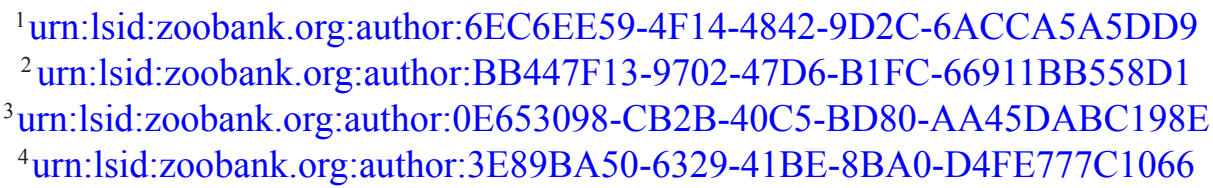

\begin{abstract}
The majority of meiofaunal organisms have limited abilities to disperse over long distances, yet they may still have disjointed distributions. Many studies have found evidence of long distance meiofauna dispersal due to passive transport by wind and/or animals that serve as vectors for these widespread distributions. Our research on an archipelago in northeast Brazil uncovered a species of freshwater gastrotrich that at first sight appeared to be a 'cosmopolitan' species that had surpassed the connectivity constraint to occupy an island more than $350 \mathrm{~km}$ from the mainland. However, through an integrative approach using molecular sequences and morphology, we have uncovered evidence of a pseudo-cryptic species in this freshwater gastrotrich. Polymerurus insularis sp. nov. closely resembles its congeners and can easily be mistaken for similar species such as P. nodicaudus, a cosmopolitan gastrotrich. Unique to $P$. insularis sp. nov. are (1) a cuticular armature composed of simple spined scales with polygonal shape (Type 1 scales), (2) a single, spineless dorsal scale with a triangular shape located terminally next to the furca base (Type 2 scale), (3) a spineless zone composed by a patch lacking cuticular ornamentation and flat, rounded or polygonal scales without spines (Type 4 scales) (4) particular sets of terminal spined or keeled scales located both dorsally and ventrally around the furca base (Types 3, 5, 6, 7 and 8 scales). The presence of this species on a volcanic island is discussed, as is the relationship between pseudocryptism and dispersal in gastrotrichs and other meiofauna.
\end{abstract}

Keywords. Dispersion, meiofauna paradox, ubiquity, cosmopolitanism, integrative taxonomy.

Magpali L., Machado D.R.P., Araújo T.Q. \& Garraffoni A.R.S. 2021. Long distance dispersal and pseudo-cryptic species in Gastrotricha: first description of a new species (Chaetonotida, Chaetonotidae, Polymerurus) from an oceanic island with volcanic rocks. European Journal of Taxonomy 746: 62-93.

https://doi.org/10.5852/ejt.2021.746.1319 


\section{Introduction}

The spatial distributions of freshwater organisms are usually restricted by discrete boundaries, as they are surrounded by land patches without obvious connections. However, these organisms can display a much wider geographic distribution, which might be correlated to their dispersal - that is, the movement of individuals or propagules - between discrete habitats (Bilton et al. 2001; Bohonak \& Jenkins 2003). This dislocation allows organisms to reach and occupy new places beyond their original area, thus expanding the spatial distribution of their populations.

Although several mechanisms of dispersion are known, it can roughly occur in two major ways: actively or passively (Bilton et al. 2001; Bohonak \& Jenkins 2003; Coughlan et al. 2017). Active dispersion occurs when the organism itself is responsible for its own displacement (e.g., areal flight), while passive dispersion consists in movements that are generated by external agents (e.g., vectors, wind, or water currents) (Bilton et al. 2001).

Regarding meiofaunal organisms - i.e., individuals that are able to pass through a $500 \mu \mathrm{m}$ sieve, but are retained by a $42 \mu \mathrm{m}$ (Giere 2009) - active dispersion is very restricted, due to their small size, absence of a larval phase and a low capacity of movement, making it harder to cover great distances (Giere 2009; Cerca et al. 2018).

Gastrotricha Metschnikoff, 1865 is a meiobenthic metazoan taxon with individuals that range from $50 \mu \mathrm{m}$ up to $3500 \mu \mathrm{m}$ in total body length (Balsamo et al. 2014; Kieneke \& Schmidt-Rhaesa 2015). Gastrotrichs are commonly found in the benthos of marine, estuarine and freshwater environments across the globe. They are easily recognizable by the presence of adhesive tubes and a characteristic locomotory ciliation that is restricted to their ventral body surface, after which the phylum is named - from the Greek gaster: gut/stomach + thrix: cilia/hair (Balsamo et al. 2014; Kånneby \& Hochberg 2015; Kieneke \& Schmidt-Rhaesa 2015). The phylum comprises nearly 880 valid species, which are classified into two orders (Balsamo et al. 2015; Kieneke \& Schmidt-Rhaesa 2015): Macrodasyida Remane, 1925 (Rao \& Clausen 1970) and Chaetonotida Remane, 1925 (Rao \& Clausen 1970). The first order currently contains 384 nominal species, mostly marine, with a vermiform body plan and many adhesive tubes distributed along the length of the body (Todaro et al. 2019); only four freshwater species are known (Ruttner-Kolisko 1955; Kisielewski 1987; Todaro et al. 2012; Kånneby \& Kirk 2017; Garraffoni et al. 2019a). The second order, Chaetonotida, is composed of approximately 494 species of tenpin-like organisms, most with only one pair of posterior adhesive tubes (Balsamo et al. 2014; Kieneke \& Schmidt-Rhaesa 2015). Approximately two-thirds of the species are described from continental freshwaters (Balsamo et al. 2008; Balsamo et al. 2020), while the remainder are marine or estuarine.

The family Chaetonotidae Gosse, 1864, is the most specious family within Chaetonotida and indeed also Gastrotricha, with 410 species distributed in two subfamilies and 14 genera (Kolicka et al. 2016; Garraffoni et al. 2017). Chaetonotids show a wide diversity of morphologies, especially regarding body shape, size, and cuticular ornamentation (Balsamo et al. 2014; Kieneke \& Schmidt-Rhaesa 2015; Kånneby 2016). The genus Polymerurus Remane, 1927 contains exclusively freshwater species and has the largest representatives among chaetonotids, with total body lengths reaching $770 \mu \mathrm{m}$ (Kisielewski 1991; Hochberg 2005). Besides their elongated bodies, other typical features of this genus include a cephalion (cephalic plate) with lateral expansions (pleurae), adhesive tubes strongly reduced and furcal rami showing an apparent segmentation pattern (Kisielewski 1991; Kieneke \& Schmidt-Rhaesa 2015). These characteristics can vary a lot among species (Kisielewski 1991; Hochberg 2005) and the existence of intraspecific variability has also been observed (Kisielewski 1979, 1991). 
Most of the diversity documented in Polymerurus comes from species described in the Northern Hemisphere (Europe: Remane 1927; Kisielewski 1979, 1981; Balsamo 1983; Martin 1990; Schwank 1990; Nesteruk 2004; Grilli et al. 2008, 2010; Kånneby 2011; Kieneke \& Hochberg 2012; Balsamo et al. 2015; Middle East: Kisielewski 1999; North America: Brunson 1950; Packard 1956, 1959; Schwank \& Kånneby 2014; Asia: Saito 1937; Lee \& Chang 2000). Only a few species are documented from the southern hemisphere, including both 'cosmopolitan' species and newly described taxa from specific geographic regions (South America: Grosso \& Drahg 1986; Kisielewski 1991; India: Sharma \& Sharma 1990; Australia: Hochberg 2005).

In spite of the worldwide distribution of the taxon Polymerurus, current knowledge on its diversity is scarce and poorly established. As far as the number of species included in this genus is concerned, there is still no consensus in the literature (see Supp. file 1). To date, there may be 15 to 18 species in the genus (Balsamo et al. 2009; Kieneke \& Schmidt-Rhaesa 2015; Todaro 2019; WoRMS 2019). This variation arises due to disagreement among the authors about the taxonomic status of some species, either by recognizing (or not) species inquirenda or by debating the validation of synonymous species (see Supp. file 1). This lack of agreement has created confusion within the taxon and can impede our knowledge about its diversity as well as its biogeography. It is therefore important to consider how such difficulties reported above have affected present knowledge about a species' distribution. For example, the two most commonly reported species, P. nodicaudus (Voigt, 1901) and P. rhomboides (Stokes, 1887), are currently acknowledged as cosmopolitan and have been reported in inland waters of Australia, across the Middle East, Asia, Europe, North and South America (e.g., Kisielewski 1979, 1991, 1999; Lee \& Chang 2000; Hochberg 2005; Kånneby 2011; Schwank \& Kånneby 2014). However, several of these reports provide descriptions that are insufficient to distinguish $P$. nodicaudus and $P$. rhomboides from other species of Polymerurus, suggesting that this apparent cosmopolitanism could be the result of the methodological limitations of past studies.

Recent descriptions of new species of gastrotrichs have been increasingly employing updated techniques to describe and better understand their morphological variation, such as optical microscopy with Differential Interference Contrast (DIC), Scanning (SEM) and Transmission (TEM) Electron Microscopy, and Confocal Laser Scanning Microscopy (CLSM) (Todaro et al. 2015; Kieneke \& Nikoukar 2017; Garraffoni et al. 2019a; Bosco et al. 2020). The use of these tools allows an enhanced quality of observation of species-specific characteristics, which was not accessible in the past (Balsamo et al. 2008, 2014).

The present study aims at describing a new species of the genus Polymerurus that was discovered in freshwater systems of an oceanic volcanic island located in northeast Brazil. The Fernando de Noronha archipelago is situated more than $350 \mathrm{~km}$ from the American Continent (Teixeira et al. 2003) and was formed around 8 to $12 \mathrm{Ma}$ ago by volcanic activity (Cordani et al. 2004). Prior to our current study, no gastrotrichs have been described from the archipelago, whose distance from the continent likely poses a dispersion challenge to tiny, freshwater invertebrates such as the representatives of Polymerurus. The new species described herein is documented using an integrated approach combining both optical microscopy (DIC and SEM) and molecular sequencing (rDNA nuclear genes $18 \mathrm{~S}$ and $28 \mathrm{~S}$ sequencing) in order to differentiate it from the 'cosmopolitan' species that have caused confusion in this taxon.

\section{Material and methods}

\section{Sampling area}

Fernando de Noronha is an archipelago formed by volcanic activity (with soils that belong to the classes: Cambisoils, Vertisoils and Neosoils) during the Upper Miocene, around 8 to $12 \mathrm{Ma}$ ago 
(Marques et al. 2014). This territory encompasses an 18 island complex situated at approximately $365 \mathrm{~km}$ from the brazilian coast, with a total area of $18.4 \mathrm{~km}^{2}, 90 \%$ of which is occupied by the main island (Silva e Silva \& Olmos 2006). The archipelago has a tropical climate with oceanic domain of AW type, according to Koppen's classification (hot and humid with summer-autumn rains), with two well defined seasons: a dry season from August to January and a rainy season from February to July (Alvares et al. 2014). Average annual temperature is about $25^{\circ} \mathrm{C}$ (ranged $\pm 4^{\circ} \mathrm{C}$ ), while average annual rain precipitation is of $1300 \mathrm{~mm}$, although showing great interannual variation. The archipelago shows predominantly deciduous vegetation, resembling what is found in Northeast Brazil's subregion Agreste (Teixeira et al. 2003). Samples from the uppermost sediment layer of the Xaréu reservoir $\left(3^{\circ} 85^{\prime} \mathrm{S}-32^{\circ} 42^{\prime} \mathrm{W}\right.$ - Fig. 1) were collected in August 2015, stored in plastic containers and gastrotrichs were extracted at the Laboratory of Evolutionary Meiofaunal Organisms, University of Campinas (Campinas, Brazil).

\section{Differential Interference Contrast Microscopy (DIC)}

Sorting and extraction of living organisms from the sediment were carried in the laboratory, following protocol as reported by Balsamo et al. (2014). Small amounts of sediment were filtered in a $42 \mu \mathrm{m}$ mesh sieve, poured into a Petri dish and sorted under a Zeiss Stemi 2000 stereo microscope. Living animals were isolated and singly mounted in glass slides, narcotized with Magnesium Chloride $2 \%$ and observed using a Zeiss Axio Imager M2 light microscope equipped with Differential Interference Contrast (DIC) and AxioCam MRC5 digital video camera.
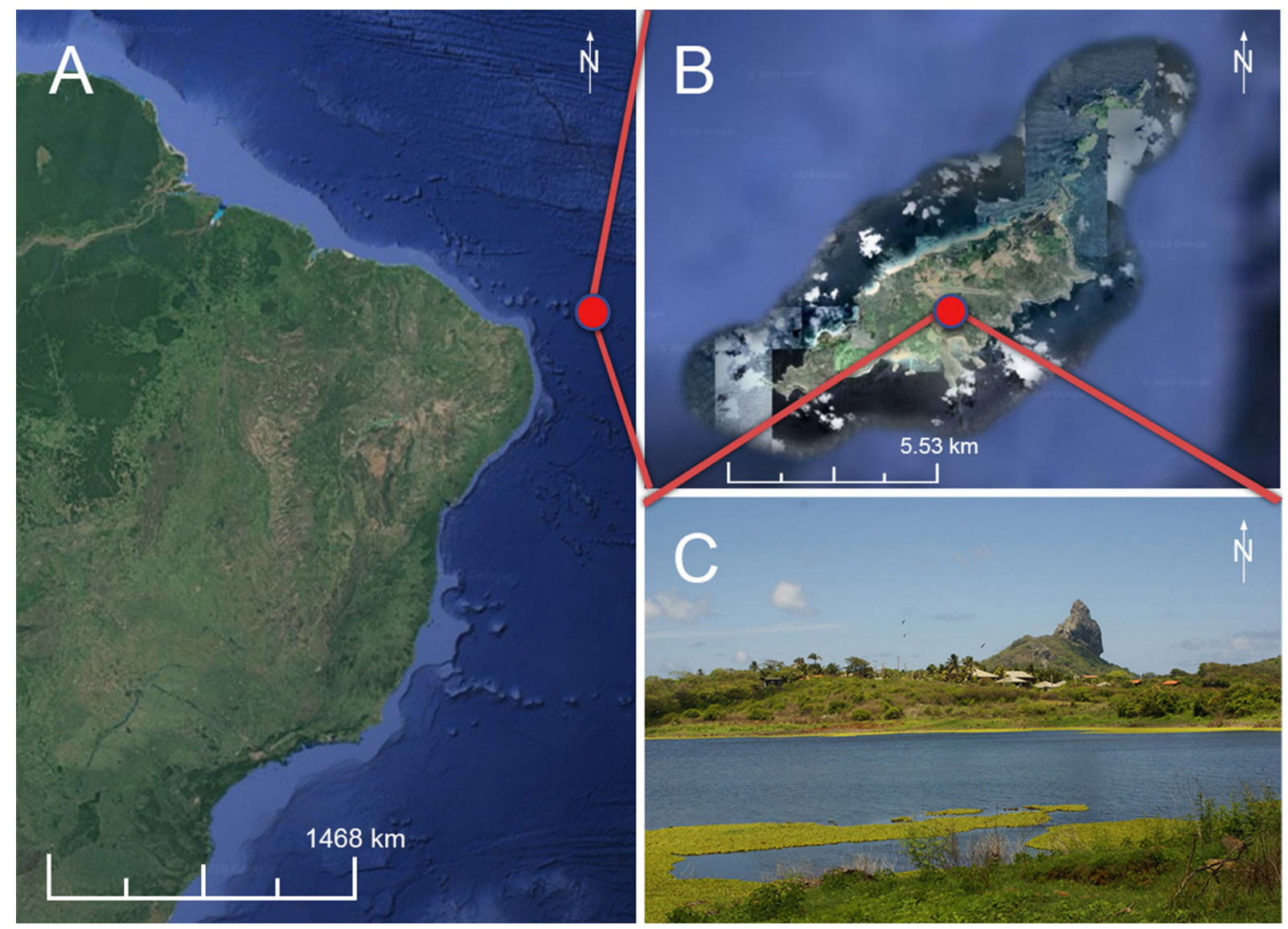

Fig. 1. Sampling location, at the state of Pernambuco, Fernando de Noronha archipelago, Brazil A. Brazil. B. Fernando de Noronha Archipelago. C. Xaréu açude. Images provided by Google Earth (A-B) and Prof Dr Felipe Toledo, University of Campinas (C). 
According to Hummon et al. (1992), the measuring parameter U was employed to elaborate the description of the new species, which varies from 1-100 and generically corresponds to a size proportion, in which the anterior-most portion of the head corresponds to the value 1, and the posteriormost end is set as 100 .

\section{Scanning Electron Microscopy (SEM)}

Specimens extracted under stereo microscope were fixed in $2.5 \%$ glutaraldehyde in $0.2 \mathrm{M}$ cacodylate buffer $\left(\mathrm{pH}\right.$ 7.4) at room temperature and stored within fixative for a few months at $4{ }^{\circ} \mathrm{C}$. The organisms were dehydrated through a series of ethanol solutions with increasing concentrations $(20 \%, 30 \%, 40 \%$, $50 \%, 60 \%, 70 \%, 95 \%, 100 \%$ ), dehydrated using hexamethyldisilazane (HMDS) (Hochberg \& Litvaitis 2000), mounted onto aluminum stubs, and coated with gold-palladium using sputter coating (Baltec SCD 050). They were observed under a JSM 5800LV scanning electron microscope at an accelerating voltage of $10 \mathrm{kV}$. The images were recorded with Semafore software (ver. 5.2) at the Laboratory of Electron Microscopy of the Biology Institute, University of Campinas.

\section{DNA extraction and amplification}

In order to obtain the coding sequences of ribosomal subunits $18 \mathrm{~S}$ and $28 \mathrm{~S}$, nuclear DNA was extracted separately from each of the three specimens of the new species using a QIAamp DNA Micro Kit (Qiagen), according to the manufacturer's instructions. Amplification via PCR was carried using a reaction mix with $3 \mu \mathrm{L}$ of genomic DNA, $12.5 \mu \mathrm{L}$ of Taq PCR Master Mix (Qiagen), 8.7 $\mu \mathrm{L}$ of nuclease-free water and $0.4 \mu \mathrm{L}(4 \mathrm{pmol})$ of specific primers. Primer sequences and PCR protocols were implemented by Garraffoni et al. (2019a). Amplification products were analyzed through agarose gel electrophoresis, using a $1 \%$ gel with $\mathrm{SYBR}^{\circledR}$ Green (Life Technologies). DNA fragments were sequenced via BigDye Terminator reaction in a 3730XL (Applied Biosystems) DNA analyzer at the Central Laboratory of High Performance Technologies - LaCTAD (Campinas, Brazil). The obtained sequences for 18S rDNA and 28S rDNA were deposited in GenBank under the following access numbers: MT711236-MT711237 (18S) and MW300430 (28S).

\section{Phylogenetic analyses}

Coding sequences of subunits $18 \mathrm{~S}$ and $28 \mathrm{~S}$ of two specimens of the new species along with 31 sequences of 29 Gastrotricha species (Table 1), were aligned using MAFFT ver. 7 on the online server (strategy G-INS-i) (Katoh et al. 2019). Alignments were visually inspected for misaligned regions and manually corrected using AliView ver. 2018 (Larsson 2014). The 28S subunit coding sequence for the second specimen of the new species was excluded due to high levels of misalignment and uncertain nucleotides. Both DNA alignments were concatenated on Sequence Matrix (Vaidya et al. 2011) and maximum likelihood phylogenetic trees were generated with W-IQ-TREE multicore ver. 1.6.11 (Trifinopoulos et al. 2016). In order to evaluate branch support of the consensus trees, Ultrafast Bootstrap Analysis was performed with 10000 bootstrap replicates, 1000 maximum iterations and a minimum correlation coefficient of 0.99 . The following single branch tests were conducted to access the support for Maximum Likelihood Trees: SH-aLRT branch test, set for 5000 replicates, and Approximate Bayes test, to maximize the confidence of the tree. Default setting was maintained for the remaining available parameters and the best-fit model based on ModelFinder analysis was GTR $+\mathrm{F}+\mathrm{I}+\mathrm{G} 4$ (GTR $=$ General Time Reversible with unequal rates and unequal base frequencies (Tavaré 1986) $+\mathrm{F}=$ Empirical codon frequencies counted from the data $+\mathrm{I}=$ allowing for a proportion of invariable sites $+\mathrm{G} 4=$ discrete Gamma model (Yang 1994) with default 4 rate categories). 
MAGPALI L. et al., New species of Gastrotricha from an oceanic island

Table 1. Taxa included in this study, with GenBank accession numbers of $18 \mathrm{~S}$ and $28 \mathrm{~S}$ rDNA sequences.

\begin{tabular}{|c|c|c|c|}
\hline Species & 18s & $28 \mathrm{~S}$ & Reference \\
\hline \multicolumn{4}{|l|}{ Family Chaetonotidae } \\
\hline Arenotus strixinoi Kisielewski, 1987 & JQ798537 & JQ798608 & Kånneby et al. (2013) \\
\hline Aspidiophorus polystictos Balsamo \& Todaro, 1987 & JQ798598 & JQ798665 & Kånneby et al. (2013) \\
\hline Aspidiophorus tetrachaetus Kisielewski, 1986 & JN185505 & JN185540 & Kånneby et al. (2012) \\
\hline Bifidochaetus arcticus Kolicka \& Kisielewski, 2016 & KP713403 & KP713404 & Kolicka et al. (2016) \\
\hline Chaetonotus acanthodes Stockes, 1887 & JQ798585 & JQ798624 & Kånneby et al. (2013) \\
\hline Chaetonotus aemilianus Balsamo, 1978 & JQ798556 & JQ798626 & Kånneby et al. (2013) \\
\hline Chaetonotus daphnes Balsamo \& Todaro, 1995 & JQ798549 & JQ798621 & Kånneby et al. (2013) \\
\hline Cephalionotus kisielewskii Garraffoni et al., 2017 & KX159486 & - & Garraffoni et al. (2017) \\
\hline Halichaetonotus aculifer (Gerlach, 1953) & JQ798550 & JQ798622 & Kånneby et al. (2013) \\
\hline Halichaetonotus paradoxus (Remane, 1927) & JQ798599 & JQ798666 & Kånneby et al. (2013) \\
\hline Heterolepidoderma acidophilum Kånneby et al., 2012 & JN185462 & JN185521 & Kånneby et al. (2012) \\
\hline Heterolepidoderma macrops Kisielewski, 1981 & JN185469 & JN185515 & Kånneby et al. (2012) \\
\hline Ichthydium squamigerum Balsamo \& Fregni, 1995 & JQ798607 & JQ798674 & Kånneby et al. (2013) \\
\hline Ichthydium skandicum Kånneby et al., 2009 & JQ798573 & JQ798673 & Kånneby et al. (2013) \\
\hline Lepidochaetus brasilense Kisielewski, 1991 & JN185495 & JQ798658 & Kånneby et al. (2013) \\
\hline Lepidochaetus zelinkai (Grünspan, 1908) & JN185486 & JQ798643 & Kånneby et al. (2013) \\
\hline Lepidodermella intermedia Kånneby et al., 2012 & JN185468 & JN185514 & Kånneby et al. (2012) \\
\hline Lepidodermella squamata (Dujardin, 1841) & JN185479 & KC193103 & Kånneby et al. (2012) \\
\hline Polymerurus nodicaudus (Voigt, 1901) - TK205 & JN185490 & JN185531 & Kånneby et al. (2012) \\
\hline Polymerurus nodicaudus (Voigt, 1901) - TK78 & JN185502 & JN185537 & Kånneby et al. (2012) \\
\hline Polymerurus rhomboides (Stokes, 1887) - TK207 & JQ798584 & JQ798715 & Kånneby et al. (2012) \\
\hline Polymerurus rhomboides (Stokes, 1887) - TK217 & JN185493 & JN185533 & Kånneby et al. (2012) \\
\hline \multicolumn{4}{|l|}{ Family Dasydytidae } \\
\hline Dasydytes carvalhoae Kisielewski, 1991 & JQ798570 & JQ798639 & Kånneby et al. (2013) \\
\hline Dasydytes elongatus Kisielewski, 1991 & JQ798568 & JQ798656 & Kånneby et al. (2013) \\
\hline Ornamentula paraënsis Kisielewski, 1991 & JQ798562 & JQ798632 & Kånneby et al. (2013) \\
\hline Stylochaeta fusiformis (Spencer, 1890) & JN185471 & JN185517 & Kånneby et al. (2012) \\
\hline Stylochaeta scirtetica Brunson, 1950 & JN185492 & JN185532 & Kånneby et al. (2012) \\
\hline \multicolumn{4}{|l|}{ Family Neogosseidae } \\
\hline Kijanebalola devestiva Todaro et al., 2013 & KR822112 & KR822118 & Kånneby \& Todaro (2015) \\
\hline Neogossea acanthocolla Kisielewski, 1991 & KR822114 & KR822119 & Kånneby \& Todaro (2015) \\
\hline \multicolumn{4}{|l|}{ Family Xenotrichulidae } \\
\hline Draculiciteria tesselata (Renaud-Mornant, 1968) & JN185470 & JN185516 & Kånneby et al. (2012) \\
\hline Xenotrichula intermedia Remane, 1934 & JF357664 & JF357712 & Todaro et al. (2011) \\
\hline
\end{tabular}




\title{
Results
}

\section{Taxonomic description}

\author{
Phylum Gastrotricha Metschnikoff, 1865 \\ Order Chaetonotida Remane, 1925 (Rao \& Clausen 1970) \\ Suborder Paucitubulatina d'Hondt, 1971 \\ Family Chaetonotidae Gosse, 1864 (sensu Garraffoni, Araújo, Lourenço, Guidi \& Balsamo, 2017) \\ Genus Polymerurus Remane, 1927 \\ Polymerurus insularis sp. nov. \\ urn:lsid:zoobank.org:pub:54D43422-15B7-4EC9-ACC9-E764D3A7BF6D
}

Figs 2-8; Tables 2-3

\section{Diagnosis}

Elongated body with head separated from the trunk by slight neck constrictions. Total body length of 215-408 $\mu \mathrm{m}$; furcal rami $93 \mu \mathrm{m}$ long with 19-21 segments per side. Three-lobed, rounded head with a well-developed cephalion showing two lateral projections; one rugous pair of lateral pleurae and a ventral hypostomium present. Body mostly covered by pentagonal or hexagonal spined scales (Type 1 scales) of various sizes $(3.5-11 \mu \mathrm{m})$ increasing in length progressively from anterior $(3.5-8.5 \mu \mathrm{m})$ to posterior body $(4.5-11 \mu \mathrm{m})$ ends and from ventral $(3.5-7 \mu \mathrm{m})$ to dorsal surface $(3.5-11 \mu \mathrm{m})$. Overall, the shape of the Type 1 scales is very distinct, with 5-6 corners and an anterior elevation that forms the spine base and opens towards a middle groove and a posterior cleavage. A triangular dorsal scale is found immediately anterior to the furca base, highly lifted and spineless (Type 2 scale). Dorsally on the furca base there is a spineless zone composed by a patch lacking cuticular ornamentation and flat, rounded or polygonal scales without spines measuring 2.5-5 $\mu \mathrm{m}$ (Type 4 scales). The posterior end of the ventral field is covered by a pair of keeled oval scales (Type 6 scales) and two pairs of small, elongated (Type 7 scales) or rounded scales (Type 8 scales), both bearing straight and long spines.

\section{Etymology}

From the Latin insularis meaning 'belonging to an island', in reference to the type locality.

\section{Material estudied}

\section{Holotype}

BRAZIL • adult (photographs, the specimen was destroyed); State of Pernambuco, Fernando de Noronha archipelago, Xaréu Reservoir; ZUEC GCH 55.

Specimen was examined while still alive under a compound microscope however, due to the fragility of the body, it was destroyed and is no longer available (Garraffoni et al. 2019b). Photographs of the specimen are available at the Museum of Zoology of the University of Campinas under the access number ZUEC GCH 55 (ICZN 2017: Article 73, Recommendation 73G, Statement 45). The holotype is shown in Figs 2A-C, 3A-I and 4B, D.

\section{Paratypes}

BRAZIL -3 adults specs (micrographs, the specimens were destroyed); same collection data as for holotype; ZUEC GCH 56 to GCH $58 \cdot 2$ specs (prepared for SEM); same collection datas as for holotype; ZUEC GCH 59, GCH 60.

Specimens were examined while still alive under a compound microscope, however, due to the fragility of their bodies, they were destroyed and are no longer available (Garraffoni et al. 2019b). Photographs of the specimens are available at the Museum of Zoology of the University of Campinas, under the 
access numbers ZUEC GCH 56 to 58 (ICZN 2017: Article 73, Recommendation 73G, Statement 45). An example of paratypes are shown in Fig. 4A, C.

\section{Other material}

BRAZIL $• 8$ specs (examined while still alive under a compound microscope and, among those, three were prepared for DNA sequencing (no longer available)); same collection datas as for holotype.

\section{Description}

The description is based on both the holotype and 5 paratypes (Figs 2-8; Table 2).

HABiTus. Specimens have a slender body with total length ranging from $215 \mu \mathrm{m}$ to $408 \mu \mathrm{m}$, showing a slight neck constriction, represented by a small variation in width between the head and the neck. The cylindrical trunk is $31-55 \mu \mathrm{m}$ wide at middle body length, showing little variation in width throughout its length, except for the set apart furcal rami, which are preceded by a pronounced constriction (Fig. 2). Body widths at head, medium length and furca base are, respectively, $24-42 \mu \mathrm{m}, 31-55 \mu \mathrm{m}$ and $23-$ $25 \mu \mathrm{m}$.

HEAD. The three-lobed head is $24-42 \mu \mathrm{m}$ wide and has three sets of distinct plates. The cephalion (U1-U6) is $19-25 \mu \mathrm{m}$ long and $20-36 \mu \mathrm{m}$ wide, with a free (detached from the cuticle) posterior portion and short paired lateral projections (lappets), each 10-18 $\mu \mathrm{m}$ long, posteriorly detached from
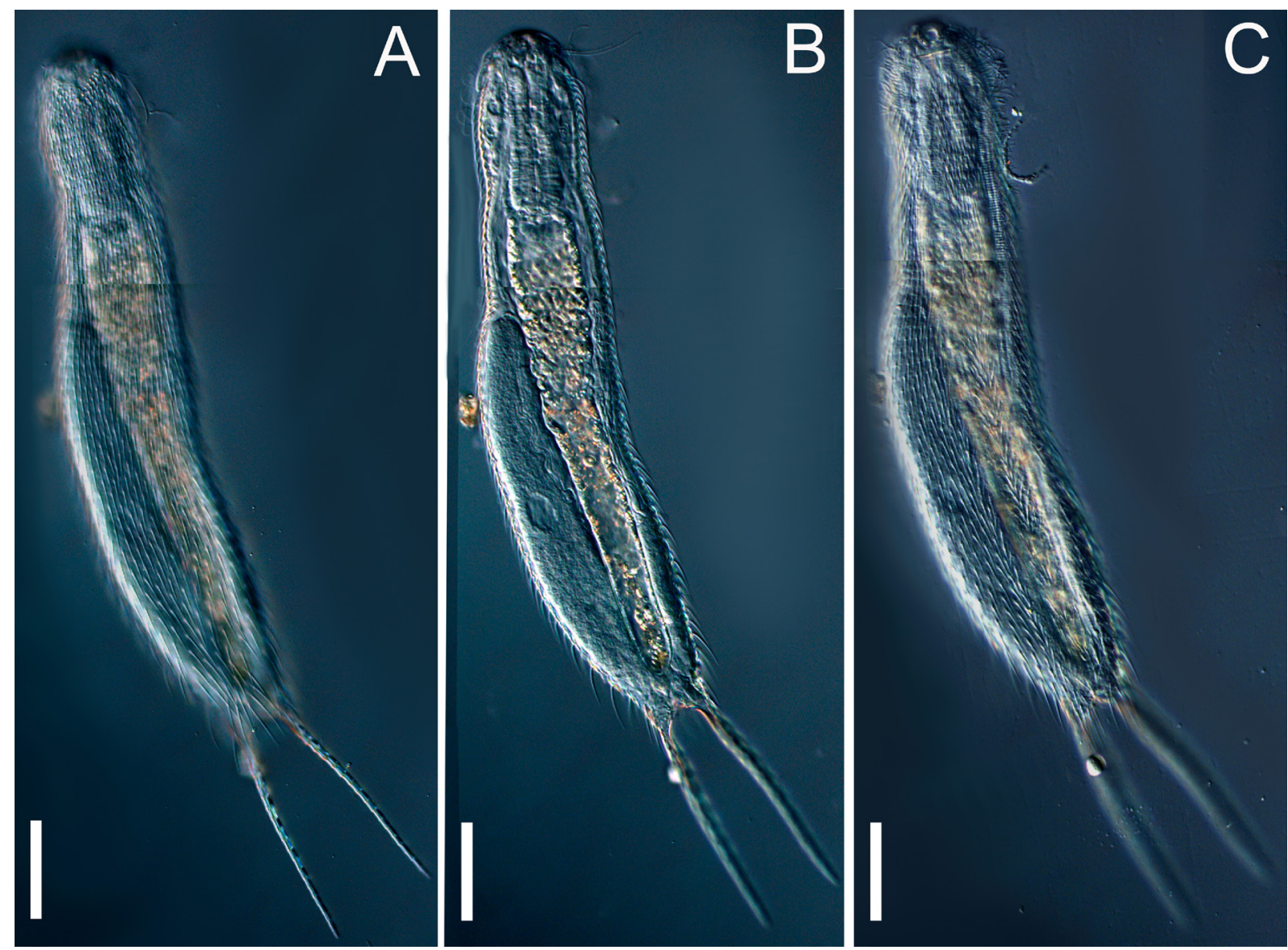

Fig. 2. Light microscopy - DIC. Polymerurus insularis sp. nov., holotype (ZUEC GCH 55). Full body view. A. Dorsal view. B. Internal view. C. Ventral view. Scale bars $=30 \mu \mathrm{m}$. 

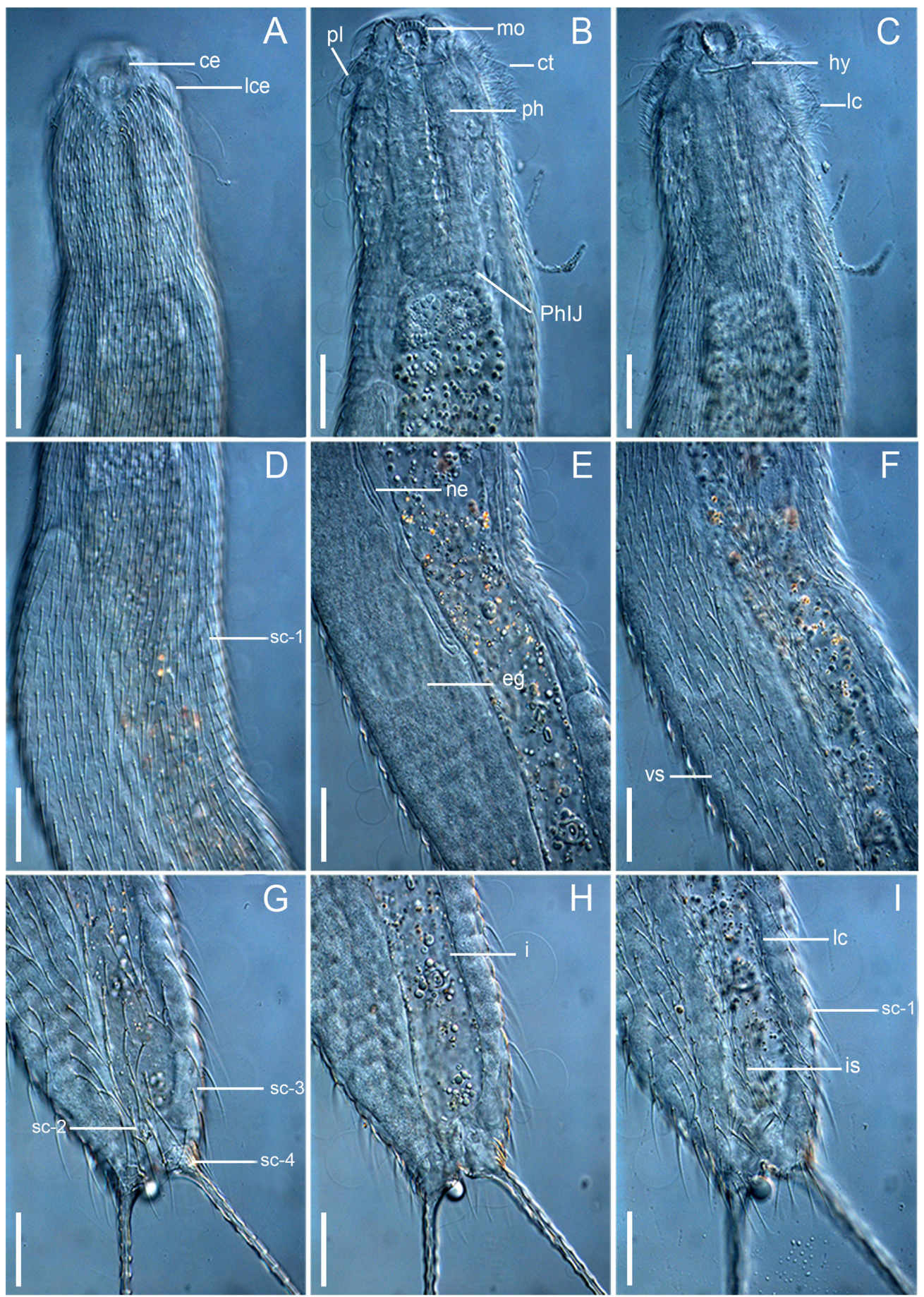

Fig. 3. Light microscopy - DIC. Polymerurus insularis sp. nov., holotype (ZUEC GCH 55). A-C. Correspond to the most anterior third of the specimen. A. Anterior dorsal region. B. Anterior internal region. C. anterior ventral region. D-F. Correspond to the trunk. D. Dorsal trunk. E. Internal trunk. F. Ventral trunk. G-I. Correspond to the posterior third of the specimen. G. Dorsal posterior third. H. Internal posterior third. I. Ventral posterior third. Abbreviations: $\mathrm{ce}=$ cephalion; $\mathrm{ct}=\mathrm{cephalic}$ bristles; eg = egg; hy = hypostomium; $\mathrm{i}=$ intestine; is = interciliary spines; $1 \mathrm{c}=$ locomotory cilia; lce = lateral cephalic expansions; $\mathrm{mo}=$ mouth; $\mathrm{ne}=$ nephridia $; \mathrm{pl}=$ pleurae; $\mathrm{ph}=$ pharynx; $\mathrm{PhIJ}=$ pharyngealintestinal junction; sc-1 = Type 1 scales; sc- 2 = Type 2 scale; sc-3 = Type 3 scales; sc- 4 = Type 4 scales; vs $=$ Type 1 ventral scale. Scale bars $=20 \mu \mathrm{m}$. 
Table 2 (continued on next page). Morphometric features of Polymerurus insularis sp. nov. All scale lengths for which the scale type is not specified are from Type 1 scales. Abbrevation: $\mathrm{N}=$ total number of measured adult specimens.

\begin{tabular}{|c|c|c|c|}
\hline Features & Range ( $\mu \mathrm{m})$ & Mean $(\mu \mathrm{m})$ & $\mathbf{N}$ \\
\hline Total body length & $215-408$ & 322 & 5 \\
\hline Body length (furcal rami excluded) & $139-308$ & 222 & 5 \\
\hline Furcal rami length & $91.5-94.5$ & 93 & 2 \\
\hline Furcal rami + adhesive tubes length & $109-117$ & 113 & 2 \\
\hline Adhesive tubes length & $16-23$ & 19.5 & 2 \\
\hline Furca base width & $26.5-27.5$ & 27 & 1 \\
\hline Number of furcal rami segments per side & $19-21$ & 20 & 1 \\
\hline Length of ornamentation bristles on the furcal rami segments & $4-8$ & 6 & 3 \\
\hline Body width at head & $24-42$ & 32 & 4 \\
\hline Body width at medium length & $31-55$ & 40 & 4 \\
\hline Body width at furca base & $23-25$ & 24 & 4 \\
\hline Diameter of mouth ring & $8-13$ & 10 & 3 \\
\hline Number of cephalic lobes & 3 & 3 & 1 \\
\hline Number of head cilia tufts & 4 & 4 & 3 \\
\hline Length of first cilia tuft & $9-12$ & 10.5 & 1 \\
\hline Length of second cilia tuft & $11-19.5$ & 14 & 1 \\
\hline Cephalion length & $19-25$ & 23 & 3 \\
\hline Cephalion width & $20-36$ & 28 & 2 \\
\hline Lateral projections (lappets) length & $10-18$ & 14 & 3 \\
\hline Pleurae length & $12-15$ & 14 & 3 \\
\hline Hypostomium length & $13-17$ & 15 & 2 \\
\hline Pharynx length & 74 & 74 & 1 \\
\hline Pharynx width at upper length & 19 & 19 & 1 \\
\hline Pharynx width at medium length & 25 & 25 & 1 \\
\hline Pharynx width at pharingeointestinal junction & 27 & 27 & 1 \\
\hline Egg width & 30 & 30 & 1 \\
\hline Protonephridia length & 105 & 105 & 1 \\
\hline Length of locomotory cilia & $5-8.5$ & 7 & 1 \\
\hline Total number of longitudinal columns of scales & 42 & 42 & 1 \\
\hline Number of scales in a single longitudinal column & 55 & 55 & 1 \\
\hline Total number of horizontal rows of scales & 64 & 64 & 1 \\
\hline
\end{tabular}


Table 2 (continued).

\begin{tabular}{lccc}
\hline Features & Range $(\boldsymbol{\mu} \mathbf{m})$ & Mean $(\boldsymbol{\mu m})$ & $\mathbf{~ N}$ \\
\hline Number of scales in a single horizontal row & 10 & 10 & 1 \\
Length of neck dorsolateral scales & $3.5-8.5$ & 6 & 4 \\
Length of middle trunk dorsal scales & $5.5-9$ & 8.5 & 2 \\
Length of middle trunk lateral scales & $6.5-11$ & 8.5 & 2 \\
Length of rear dorsolateral scales & $7.5-9$ & 6 & 2 \\
Length of rear triangular scale (Type 2) & $5-7$ & 6 & 3 \\
Length of small rounded scales with posterior spines (Type 3) & 4.5 & 4.5 & 1 \\
Length of rear dorsal small scales (Type 4) & $2.5-5$ & 3 & 1 \\
Length of rear indented scales (Type 5) & $7-8$ & 7.5 & 1 \\
Length of neck ventral scales & $3.5-5$ & 4 & 2 \\
Length of middle trunk ventral scales & 4.5 & 4.5 & 1 \\
Length of rear trunk ventral scales & $4-7$ & 5 & 1 \\
Length of keeled ventral scales (Type 6) & $9.5-10$ & 10 & 1 \\
Length of small ventral elongated scales (Type 7) & $3.5-4$ & 3.5 & 1 \\
Length of small ventral round scales (Type 8) & $4.5-7$ & 6 & 1 \\
Length of head and neck dorsolateral spines & $2-13$ & 7.5 & 2 \\
Length of upper trunk dorsolateral spines & $8-15$ & 11.5 & 2 \\
Length of middle trunk dorsolateral spines & $8.5-22.5$ & 15.5 & 5 \\
Length of rear trunk and furca base dorsolateral spines & $18-33$ & 25.5 & 5 \\
Length of neck ventral spines & $5.5-7.5$ & 6.5 & 1 \\
Length of trunk ventral spines & $5.8-9.8$ & 8 & 2 \\
Length of rear ventral spines & $5.7-15$ & 10 & 1 \\
Length of keels on Type 6 scales & $6-7$ & 6.5 & 1 \\
\hline
\end{tabular}

the head and slightly lifted (Figs 3A, 7A-C). There is a pair of pleurae (U2-U6), each 12-15 $\mu \mathrm{m}$ long and presenting a rough texture with small parallel grooves, contrasting with the smooth surface of the cephalion (Figs 3B, 7C). The ventral hypostomion is a well-marked transversal bar, at U4, 13-17 $\mu \mathrm{m}$ long and shaped like an arch (i.e., decreasing in thickness towards the lateral extremities) with a middle concavity (Fig. 3C). Two tufts of cilia (cephalic sensory bristles) are present on each side of the head. The first tuft is shorter, approximately $10.5 \mu \mathrm{m}$ long and located below the cephalion projections (U1), while the second is situated between the cephalion and the pleurae (U2), bearing longer cilia with an average length of $14 \mu \mathrm{m}$ (Fig. 3B). No dorsal sensory bristles were observed. Mouth is subterminal, with $8-13 \mu \mathrm{m}$ of diameter and surrounded by a ring that is segmented with longitudinal ridges (Fig. 3A-C). The pharynx is relatively long, reaching up to one-quarter body length (adhesive tubes excluded) and situated between U2 and U20. It is $74 \mu \mathrm{m}$ long, $25 \mu \mathrm{m}$ wide at mid-length and divided in 2 regions, without any distinct constrictions. Pharynx becomes wider towards its inferior portion at the pharyngeal 

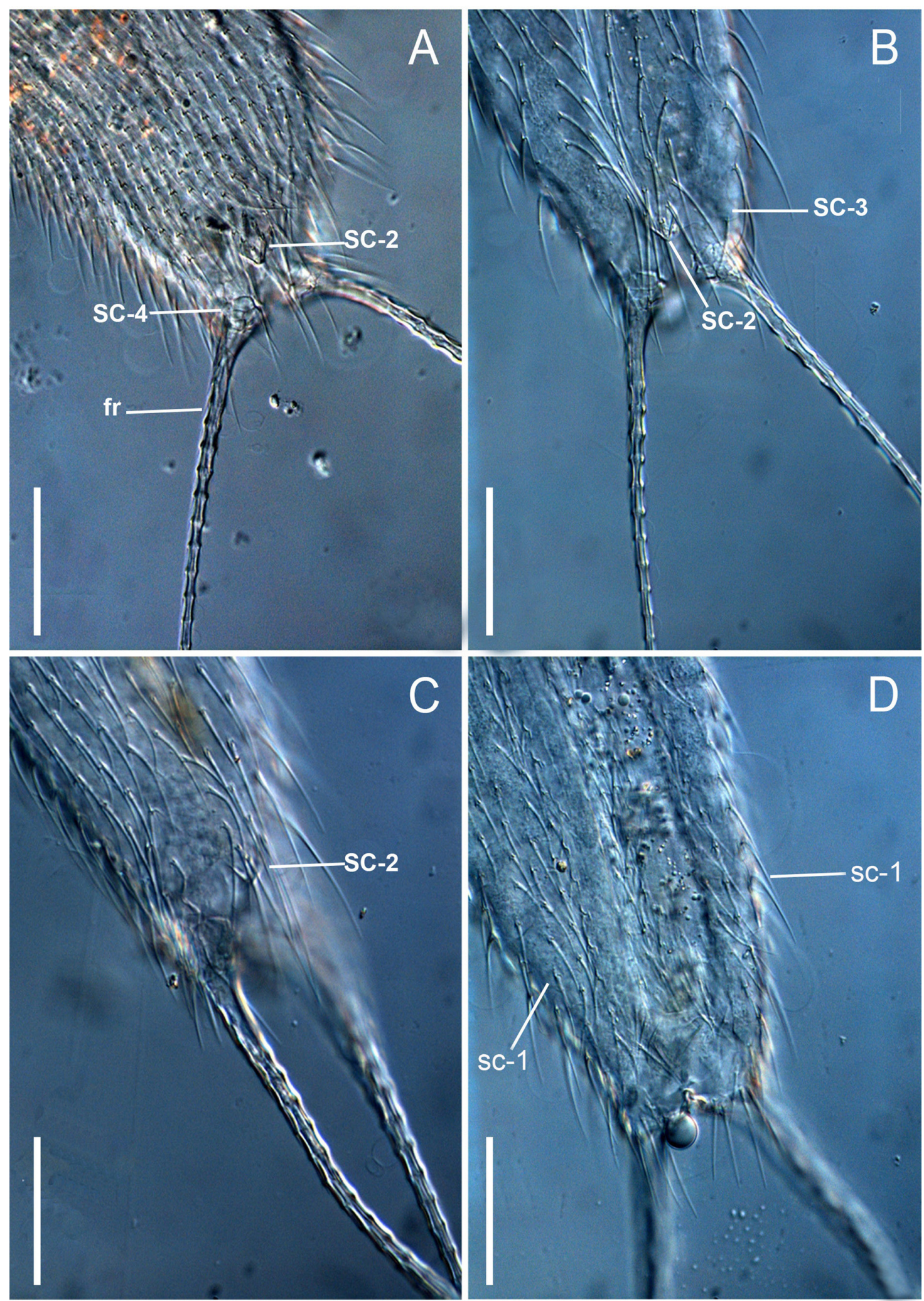

Fig. 4. Light microscopy - DIC. Polymerurus insularis sp. nov. Posterior region of the body. A. Paratype (ZUEC GCH 56). B, D. Holotype (ZUEC GCH 55). C. Paratype (ZUEC GCH 57). A-B. Posterior dorsal view. C. Posterior dorsolateral view. D. Posterior ventral view. Abbreviations: $\mathrm{fr}=$ furcal rami; sc-1 = Type 1 scales; sc-2 = Type 2 scale; sc- $3=$ Type 3 scales; sc- $4=$ Type 4 scales. Scale bars $=40 \mu \mathrm{m}$. 

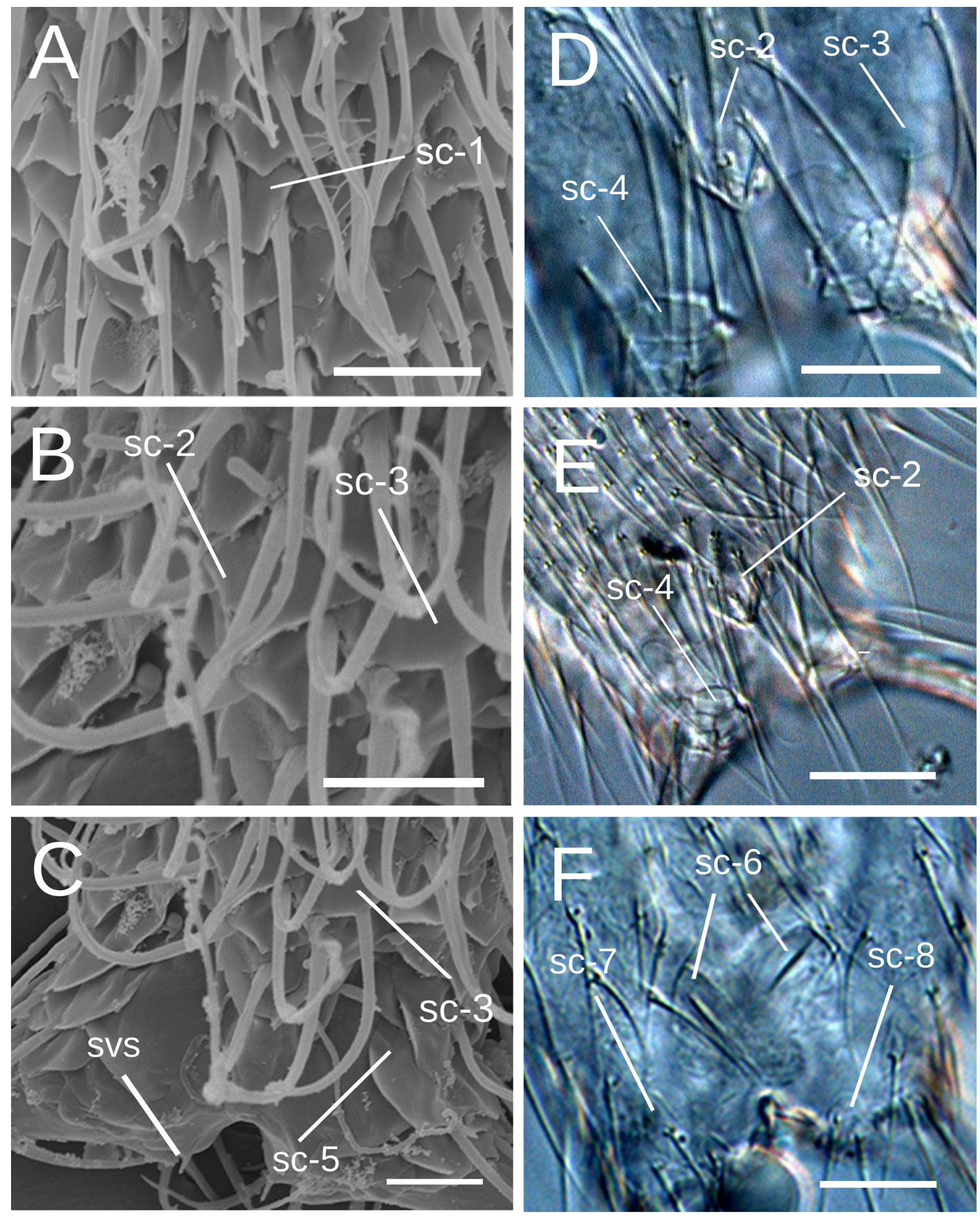

Fig. 5. Close-up of the different types of scales described for Polymerurus insularis sp. nov. A-C. Paratype (ZUEC GCH 59). D, F. Holotype (ZUEC GCH 55). E. Paratype (ZUEC GCH 56). A-C. Scanning electron microscopy. D-F. Light microscopy - DIC. A. Detail of a section of the dorsal middle trunk, showing the most common type of scale, Type 1, with emphasis on its characteristic shape. B. Detail of a section of the dorsal posterior trunk, showing Type 2 and Type 3 scales. C-E. Detail of the transition between the dorsal posterior trunk and the dorsal furca base, showing the particular scale covering of this region. F. Detail of the transition between the ventral posterior trunk and the ventral furca base, showing the particular scale covering this region. Abbreviations: sc- $1=$ Type 1 scales; sc- $2=$ Type 2 scale; sc-3 = Type 3 scales; sc- $4=$ Type 4 scales; sc- $5=$ Type 5 scales; sc- $6=$ Type 6 scales; sc- $7=$ Type 7 scales; sc- $8=$ Type 8 scales; svs $=$ small ventral pair of spines. Scale bars: $\mathrm{A}-\mathrm{C}=5 \mu \mathrm{m} ; \mathrm{D}=10 \mu \mathrm{m} ; \mathrm{E}=$ $15 \mu \mathrm{m} ; \mathrm{F}=10 \mu \mathrm{m}$. 

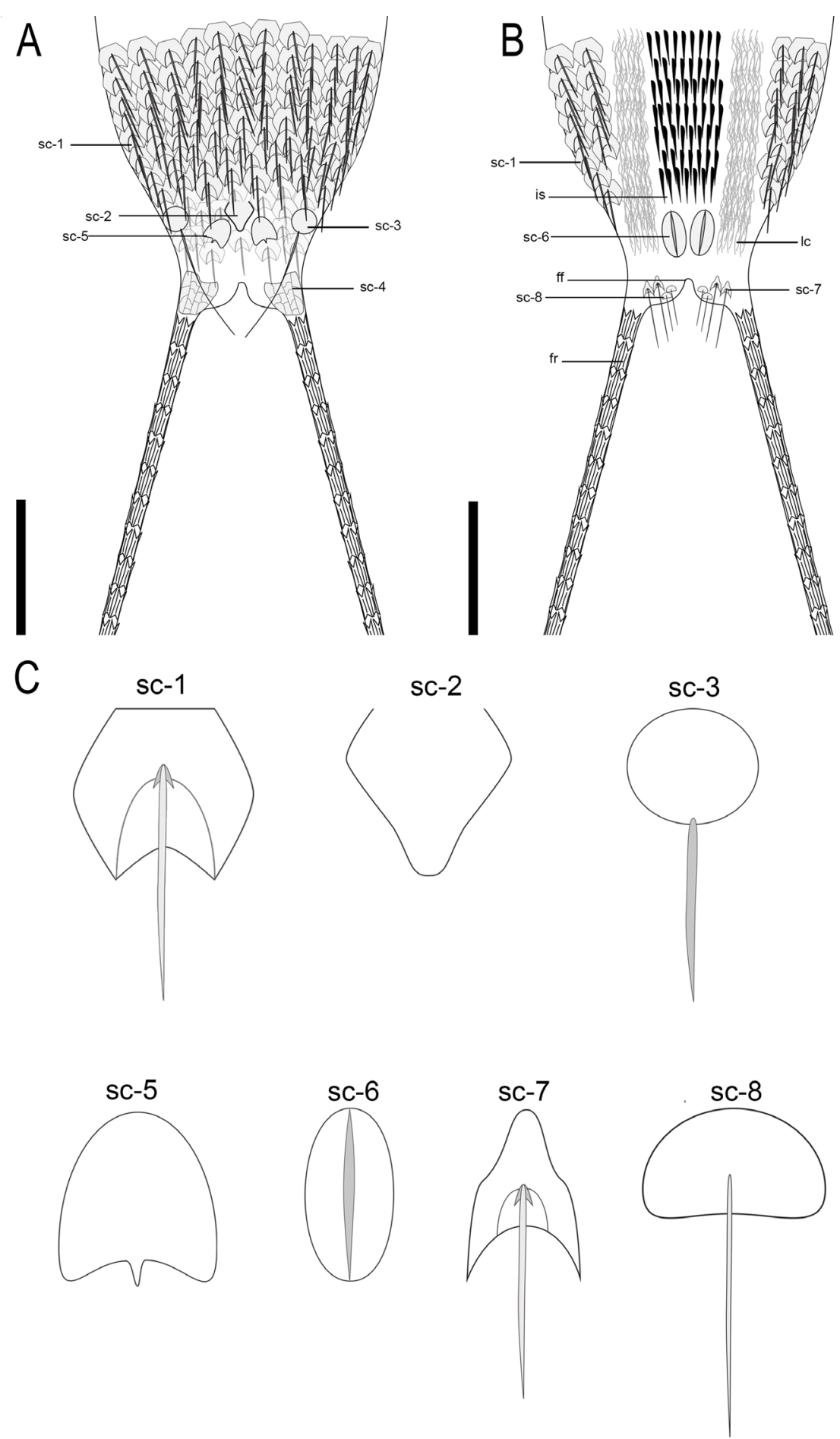

Fig. 6. Schematic illustration of dorsal and ventral posterior regions and type scales of Polymerurus insularis sp. nov. A-B. Paratype (ZUEC GCH 56). A. Dorsal view of the posterior end. Some Type 1 scales are faded for a better visualization of Types 2, 3 and 5 scales. B. Ventral view of the posterior end. C. Each type of scale, individually depicted (not to scale). Abbreviations: $\mathrm{ff}=$ furcal furrow; $\mathrm{fr}=$ furcal rami; $1 \mathrm{c}=$ locomotory cilia; is = interciliary spines; sc- $1=$ Type 1 scales; $\mathrm{sc}-2=$ Type 2 scale; sc- $3=$ Type 3 scales; sc- $4=$ Type 4 scales; sc- $5=$ Type 5 scales; sc- $6=$ Type 6 scales; sc- $7=$ Type 7 scales; sc- $8=$ Type 8 scales. Scale bars $=40 \mu \mathrm{m}$. 
intestinal junction (from $19 \mu \mathrm{m}$ to $27 \mu \mathrm{m}$ ) while at its superior end a distinct, although small, furrow is formed at the junction of the internal regions (Fig. 3B).

INTERNAL ANATOMY. Internally, a pair of protonephridia $(105 \mu \mathrm{m}$ long $)$ are present, lateral to the intestine and posterior to the pharyngeointestinal junction (U29-U75) (Fig. 3E).

FURCA. Is $109-117 \mu \mathrm{m}$ long ( $1 / 4$ of the body) and furca base is $27 \mu \mathrm{m}$ wide, showing a V-shaped gap with a large and distinct U-shaped middle furrow ("helmet like" shape, as described by Roszczak 1969). Presence of a single pair of very small ventral spines, one per side of the furrow (Fig. 5C). Furcal rami are $93 \mu \mathrm{m}$ long (around $1 / 5$ of body length) and appear to be composed of 19-21 segments (Figs 4A, 6B, $7 \mathrm{~A}, 8 \mathrm{C}$ ). Segments of the furcal rami show well marked ornamentations in both DIC and SEM images, with well defined edges and covered at both sides - sometimes almost entirely - with short, straight or slightly bent up spines (bristles) measuring around 4-8 $\mu \mathrm{m}$ (Figs 4A-C, 8D-E). These ornamentations decrease in thickness and length towards the posterior end of the furca, which seems to be partially due to the decrease in the number and length of the spines (bristles). In fact, thickness, number and length of the spines on the ornamentation are variable among the specimens (Figs 2A, 4A-C, 8D-E). The inner portion of the first $10^{\text {th }}$ of the furca length, which precedes segmentation, is smooth, while the outer portion is covered by the aforementioned bristles.

Ventral ciliature. Composed of two longitudinal bands of locomotory cilia with approximately 5-8.5 $\mu \mathrm{m}$ of length, starting at U1, immediately below the mouth line, and ending at U71, right before the location of the Type 6 scales (Figs 3C, I, 6B, 7C). Ventral ciliary bands are separated by the ventral interciliary field covered by small spined scales (Figs 3I, 6B). Although cilia are not well visible in the pictures and were not very well oriented for measurements, due to the position and preservation state of the individuals, they are depicted in the illustrated schematics (Fig. 6B).

DoRsal SCALES. Most of the cuticular armature of the body is composed of simple spined scales arranged in approximately 42 longitudinal columns, each column bearing 55 scales, and approximately 64 horizontal, alternate rows, with around 10 scales per row (Fig. 2A). Dorsolateral scales covering anterior, middle and most of the posterior body surface are roughly polygonal in shape (most presenting pentagonal or hexagonal form), with an elevated anterior portion, a distal incision and bearing a single spine (Type 1 scales - Figs 3D, 4D, 5A, 6A-C, 7D-E). These polygonal scales are the most common type found on the specimens, covering the majority of the body, both dorsolaterally and ventrally. They are outlined by five to six corners, with two distinctive elements (Figs 5A, 6A-C, 7D-E): (a) an elevated anterior portion formed by the spine's curvature - as it arises from the scale's surface at middle range, from semi triangular keels - and (b) a longitudinal concavity delimited by two sloping edges that extend from the spine's insertion to the posterior end of the scale, often ending in a gap, where the two most distal corners meet forming a wide angle. SEM images (Figs 7A, D-E, 8A-B) reveal that these scales are considerably overlapped (overlapping usually hides their anterior half). Dorsal scales arranged in the first five transversal rows are rounded, very small and rather close to each other, measuring 3.5-5.5 $\mu \mathrm{m}$ (scale type unidentified) (Fig. 3A). From the fifth transversal row, dorsal scales become predominantly polygonal (Type 1 scales), reaching $8.5 \mu \mathrm{m}$ at the pharygeointestinal junction (U20 - Fig. 3A-B, D). At the middle trunk (from the pharingeointestinal junction to the proximities of furca base, at U73U75) they range from 5.5 to $9 \mu \mathrm{m}$, while at the lateral sides they become slightly larger, measuring 6.5-11 $\mu \mathrm{m}$ (Figs 3D, I, 4D). All dorsal scales are mostly parallel to the transverse axis of the body, with the exception of one distinct elevated spineless scale immediately anterior to the furca base (U71), which is $5-7 \mu \mathrm{m}$ long and shaped as a triangle with well-marked edges (Type 2 scale - Figs 3G, 4A-C, 5B, D-E, 6A, C). Laterally and below the Type 2 scale, at U72, there is a pair of small $(4.5 \mu \mathrm{m})$ rounded scales, one at each side of the caudal field, bearing long spines $(16-21 \mu \mathrm{m})$ which arise directly from the scale's most posterior end, instead of from the middle, as it normally occurs (Type 3 scales - Figs 3G, 

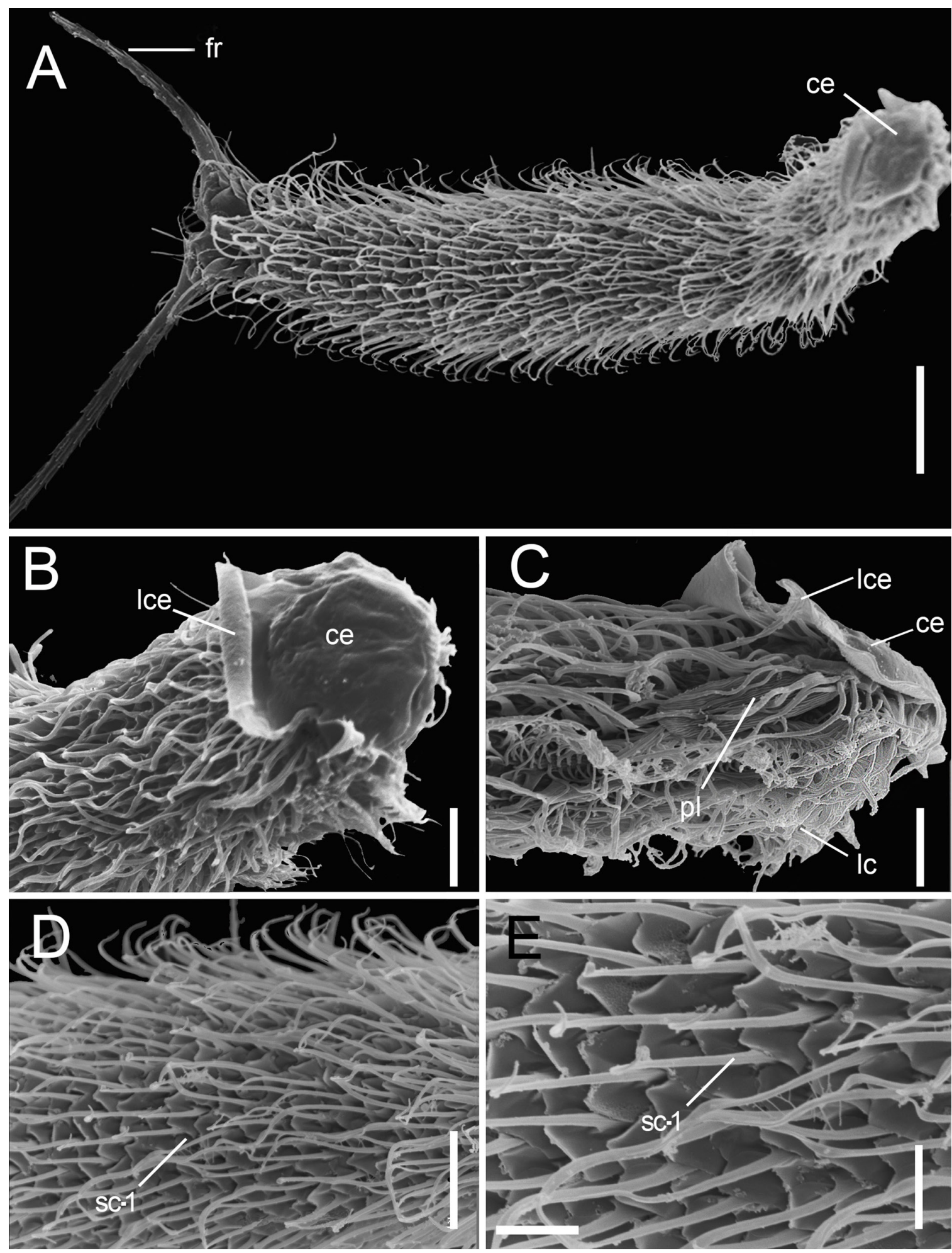

Fig. 7. Scanning electron microscopy. Polymerurus insularis sp. nov. A-B, D-E. Paratype (ZUEC GCH 59). C. Paratype (ZUEC GCH 60). A. Dorsal view of the body. B. Dorsolateral view of the head, showing the cephalion and its lateral projections. C. Lateral view of the head, highlighting the lateral pleurae. D-E. Dorsal trunk view, highlighting scale Type 1. Abbreviations: ce = cephalion; $\mathrm{fr}=$ furcal rami; $1 \mathrm{c}=$ locomotory cilia; $1 \mathrm{ce}=$ lateral cephalic expansions; $\mathrm{pl}=$ pleurae; $\mathrm{sc}-1=$ Type 1 scales. Scale bars: $\mathrm{A}=40 \mu \mathrm{m} ; \mathrm{B}-\mathrm{C}=5 \mu \mathrm{m} ; \mathrm{D}=20 \mu \mathrm{m} ; \mathrm{E}=10 \mu \mathrm{m}$. 

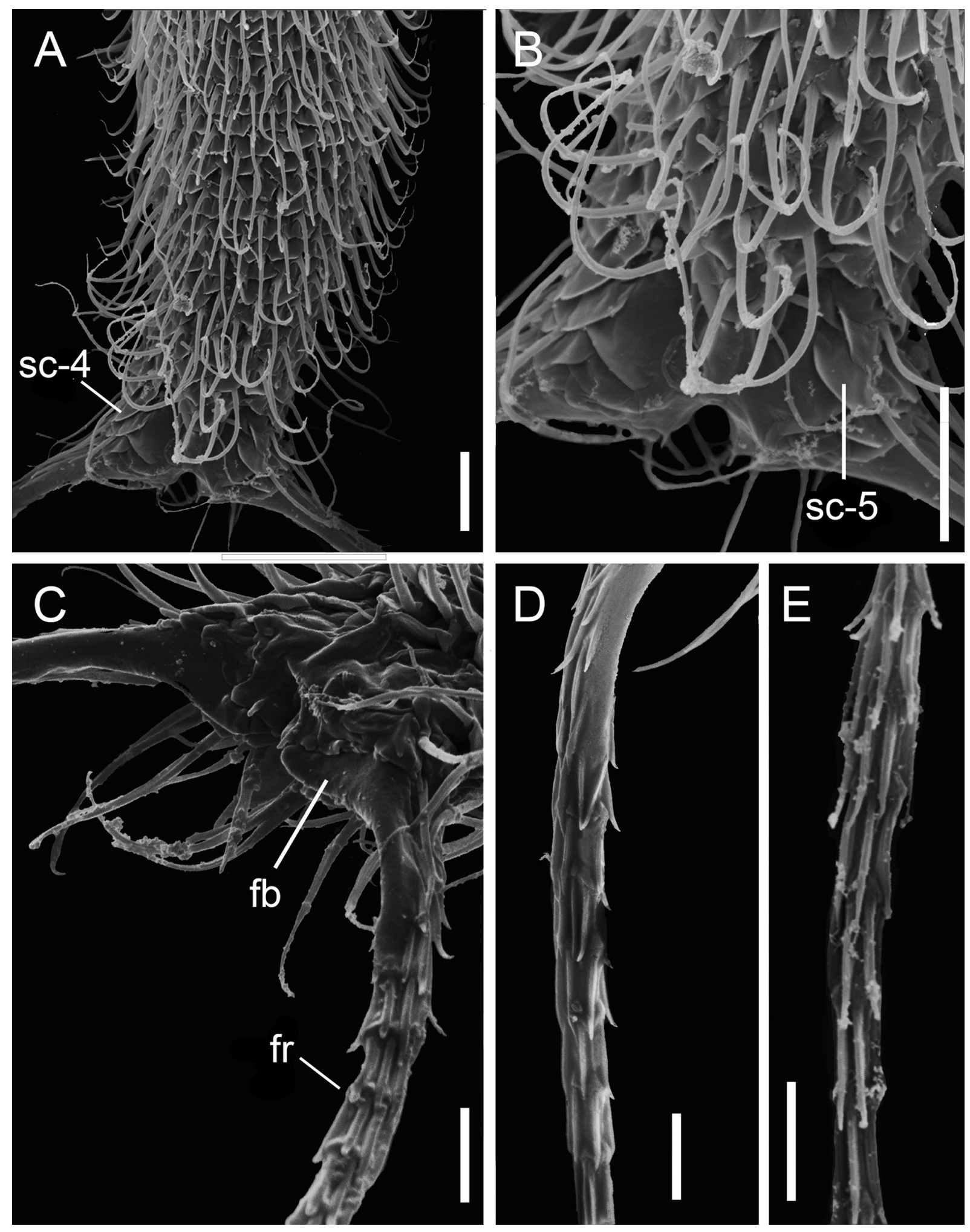

Fig. 8. Scanning electron microscopy. Polymerurus insularis sp. nov. A-B, D. Paratype (ZUEC GCH 59). C, E. Paratype (ZUEC GCH 60). A-B. Posterior dorsal view. C. Detail of the furca base in posterior dorsolateral view. D-E. Details of the furcal rami. Abbreviations: $f b=$ furca base; $f r=$ furcal rami; sc-4 = Type 4 scales; sc-5 = Type 5 scales. Scale bars $=10 \mu \mathrm{m}$. 
4B, 5B-D, 6A, C). Immediately following this region (at U62 in the paratype photographed with SEM and between U71-75 in the holotype), there is a rather noticeable spineless field covered by: (a) a patch lacking cuticular ornamentation (situated medially from the surroundings of the furca base until the uppermost portion of the adhesive tubes), and (b) a complex of small, flat, rounded or polygonal and spineless scales (U73-U75), 2.5-5 $\mu \mathrm{m}$ long, covering the initial portion of each furcal rami (Type 4 scales) (Figs 3G, 4A, 5D-E, 6A, 8A). Below Type 2 scales there is a pair of spineless, wide and rounded scales, $7.5 \mu \mathrm{m}$ long, presenting small indentations at their posterior ends (Type 5 scales - Figs 5C, 6A, C, 8B).

DoRSAL SPINES. Dorsolateral spines covering the head and neck (U1-U20) are rather short, ranging from 2-13 $\mu \mathrm{m}$. The first two rows of spines, disposed immediately around and below the cephalic plates are much shorter $(2-7 \mu \mathrm{m})$ and slightly curved, while the remaining rows along the neck contain longer and straighter spines. Through the upper and middle trunk (U21-U44), the dorsal spines increase progressively in length, with an average length of $11.5 \mu \mathrm{m}$ and $15.5 \mu \mathrm{m}$, respectively, reaching their largest dimensions at the rear trunk (U45-U51), with an average range of $25.5 \mu \mathrm{m}$. At rear trunk, towards the furca base (U75), dorsolateral spines become much longer $(18-33 \mu \mathrm{m})$ and straighter, grouping into two pairs pair of small, tight clusters at the lateral edges of the body surrounding the anterior-most portion of the furca base (Figs 2A, 3G, 4A-B). Most spines arise at a medial point on a scale's surface, under a small ridge-shaped elevation that is formed by the junction of: (a) the spine's anterior end, as it rises from the scale, and (b) the superposition between the scale's anterior portion and the posterior ends of the two scales in the former row (Figs 6A-C, 7E).

Ventral inTERCILIARY SCALES. Are small in the head and neck region $(3.5-5 \mu \mathrm{m})$ and increase in size towards the middle trunk $(4.5 \mu \mathrm{m})$ and rear trunk $(4-7 \mu \mathrm{m})$, similarly to the dorsal and lateral scales. At the posterior end of the ventral surface, the scales are rounded or polygonal and flat (unidentified type). Among these scales is situated a particular and very distinct pair of oval scales at the middle of the posterior interciliary ventral field (U71); each scale bears a keel that emerges from the anterior portion of the scale and extends across its length (Type 6 scales - Figs 5F, 6B-C). In the holotype, the largest scale of the pair is $10 \mu \mathrm{m}$ long, with a keel $6 \mu \mathrm{m}$ long, while the smaller scale is $9.5 \mu \mathrm{m}$ long, showing a $7 \mu \mathrm{m}$ long keel. However, such asymmetrical pattern might not be ubiquitous; it was only reported for the holotype because it was not possible to visualize and measure these structures in the paratypes. The most distal extremity of the ventral furca base (U75) is covered by two columns of small (3.5-7 $\mu \mathrm{m}$ long) scales (Types 7 and 8 scales) bearing spines that are very long and straight, measuring from 11 up to 20 $\mu \mathrm{m}$. These scales are elongated antero-posteriorly and laterally narrowed, showing a middle furrow and lateral projections (Type 7 scales), or rounded and antero-posteriorly narrowed (Type 8 scales) (Figs 5F, 6B-C).

Ventral INTERCILIARY SPINES. Are shorter than the dorsal spines. They range in size from $5.5-15 \mu \mathrm{m}$, and become longer and thicker from anterior to posterior region and from ventral to ventrolateral sides.

EGG. A single egg was present in the holotype (Fig. 3E); it was $30 \mu \mathrm{m}$ wide and situated between the cuticle and the intestine, extending from the upper to rear trunk (U21-U51). No sperm and reproductive organs were observed.

\section{Taxonomic remarks}

Specimens of the genus Polymerurus, when compared with the remaining members of Chaetonotida, are easily recognized due to their large size (some species are the longest known chaetonotidans), the presence of ring-like ornamentations - usually called segmentations - on the furcal rami, and a cephalion with prominent lateral expansions. Although all species of Polymerurus share these characteristics, it is possible to recognize among them very distinct morphotypes, generally based on their cuticular 


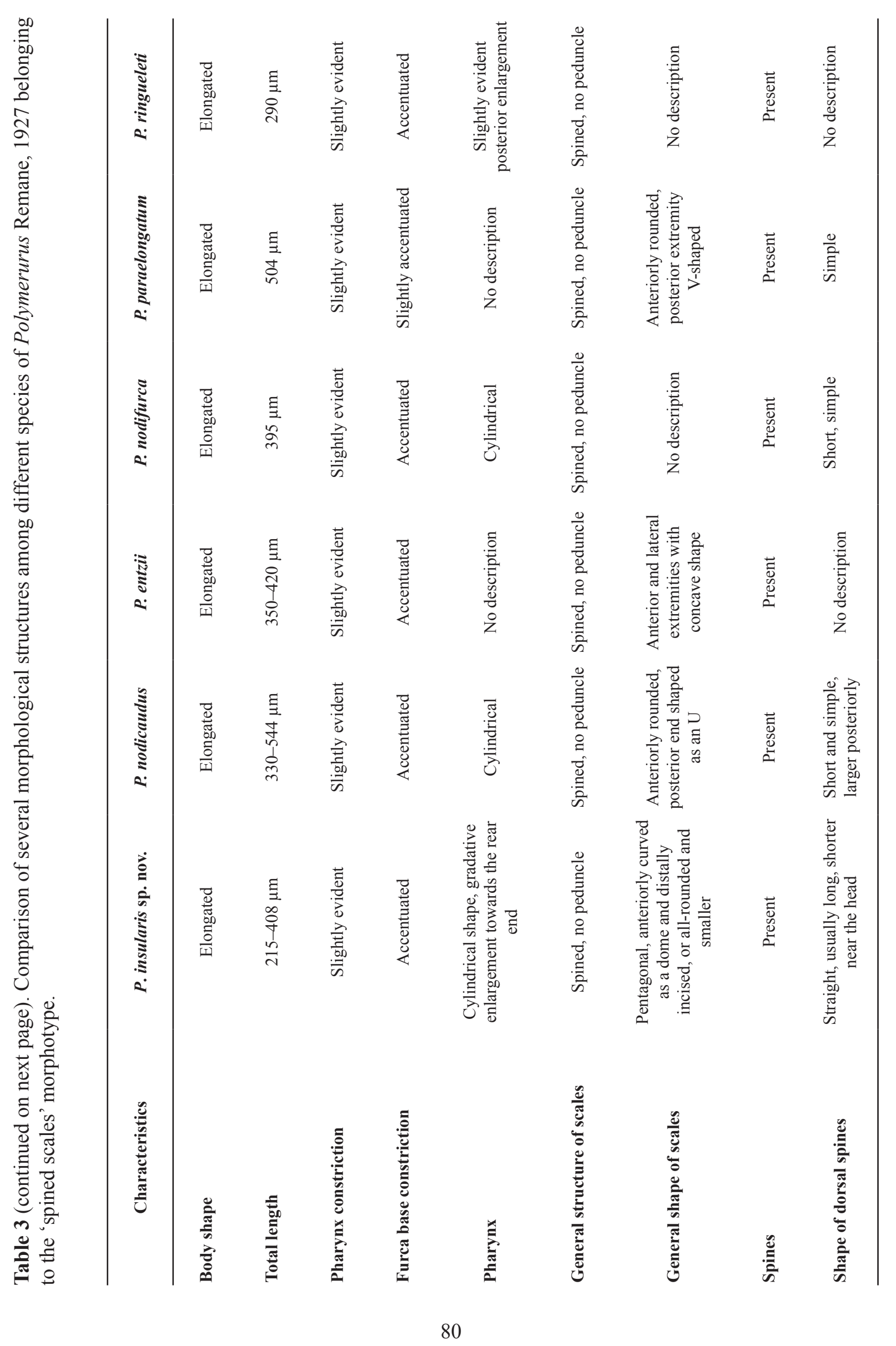




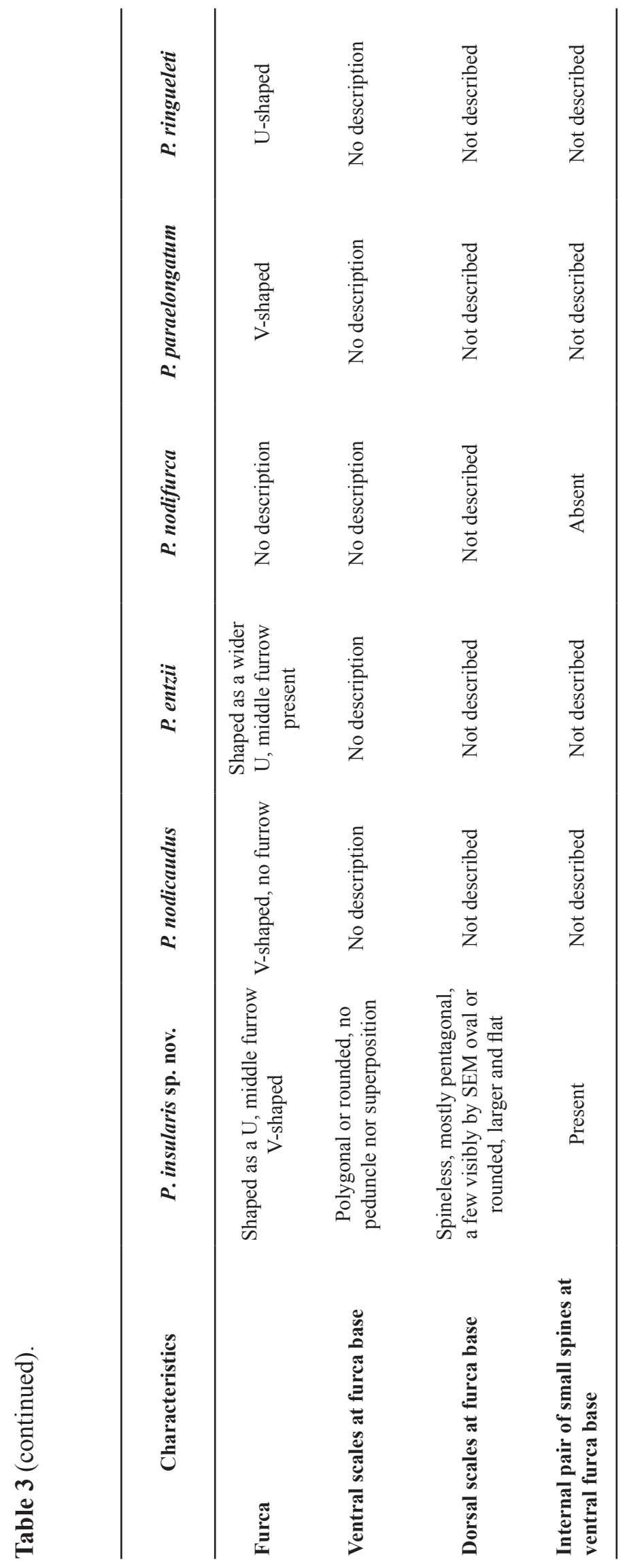


ornamentation and body outline. Regarding the latest, it is possible to distinguish completely straight outlines with absent body constrictions, as in P. serraticaudus (Voigt, 1901) from more tenpin-like shapes as occurs in $P$. rhomboides. Furthermore, the caudal portion varies in length, thickness and segmentation type (partial or complete). In what accounts for cuticular coverage, species may present spined scales that lack a peduncle (column-like base) or pedunculated scales (stalked scales). Polymerurus insularis sp. nov. bears spined scales that lack a peduncle, and in terms of cuticular coverage resembles six other species: P. nodicaudus, P. serraticaudus, P. entzii (Daday, 1882), P. nodifurca (Marcolongo, 1910), P. paraelongatus (Grosso \& Drahg, 1986) and P. ringueleti (Grosso, 1975). However, the new species has a specific set of characteristics that distinguishes it from these congeners: (1) a cuticular armature composed of simple spined scales with polygonal shape (Type 1 scales), (2) a single, spineless dorsal scale with a triangular shape located terminally next to the furca base (Type 2 scale), (3) a spineless zone composed by a patch lacking cuticular ornamentation and flat, rounded or polygonal scales without spines (Type 4 scales) (4) particular sets of terminal spined or keeled scales located both dorsally and ventrally around the furca base (Types 3, 5, 6, 7 and 8 scales). In addition to these characteristics, the new species can be differentiated from $P$. nodicaudus and $P$. paraelongatus by the presence of a $\mathrm{U}$-shaped furca instead of a V-shaped furca, and from $P$. entzii by the absence of long spines in each of the ring-like ornamentations (segments) of the furca rami. Additionally, the new species contrasts with P. nodifurca by long and straight spines instead of short, curved spines, as found in the aforementioned species. Finally, spined-scales are present along the dorsolateral, lateral and ventrolateral regions in Polymerurus insularis sp. nov., which distinguishes it from $P$. ringueleti; while the long, narrow and segmented furcal rami of the new species are very different from the short, thick and unornamented furca present in $P$. serraticaudus.

\section{Phylogenetic relationships}

The final alignments of 18S rDNA and 28S rDNA yielded 1761 and 4141 positions, respectively, while the concatenated alignment had 5902 positions. The phylogenetic reconstruction based on a multigene approach supported the currently recognized monophyly of the genus Polymerurus with a very high bayesian (1-0.98) and bootstrap (99-98) support for the phylogenetic signal on both internal and external nodes of the Maximum Likelihood (Fig. 9) and Consensus trees (Supp. file 2). Accordingly, the two specimens of Polymerurus insularis sp. nov. were grouped together and nested within Polymerurus, with branch supports of 1 and 99 . As expected, $P$. nodicaudus was recovered as sister clade to $P$. insularis sp. nov., reflecting the morphological similarities between the two species, such as spined scales with no peduncles, in contrast with the pedunculated scales of $P$. rhomboides.

\section{Discussion}

\section{Dispersal through long distances}

Freshwater gastrotrichs have previously been reported from oceanic islands (e.g., Balsamo 1982; Fregni et al. 1998; Balsamo et al. 1994; Hochberg 2005); however, Polymerurus insularis sp. nov. is the first new species to be found on an oceanic island of volcanic origin. This geological origin, together with the long geographic distance from the Brazilian coast means that the islands were never in contact with the continental lands (Silva e Silva \& Olmos 2006; Marques et al. 2014). The early physical isolation from the continents and the thousands of square kilometers of ocean surrounding the island forms a nearly unsurmountable barrier for the active dispersal of freshwater gastrotrichs (e.g., given hostile conditions such as salinity and oxygen levels). Thus, this scenario results in a very unlikely environment to be reached/accessed by a tiny freshwater invertebrate such as a gastrotrich. It is important to take into account some crucial characteristics of the gastrotrichs and other meiofaunal organisms that also play a role as a barrier to their dispersion: their microscopic body sizes, short life cycles (restrained to a few weeks), and limited swimming capacity (Higgins \& Thiel 1988; Boeckner et al. 2009; Giere 2009). 
Such evidence raises the question: how was it possible to find a freshwater gastrotrich on an oceanic island without any - present or historical - contact with the continent? A first hypothesis for this question is related to passive dispersal events, in which adult/larval individuals or their propagules are carried long distances by external agents (Cerca et al. 2018). Considering freshwater invertebrates, passive dispersal events can happen through wind gusts termed anemochory (Greek: anemo, wind, choro, dance), or via an animal vector (termed zoochory, Greek, zoo, animal) attached to feet, feathers, and fur (Bilton et al. 2001). In this case, the transported organisms are frequently at a specific stage of their life cycle in the form of a drying resistant propagule, such as a diapause egg or annhydrobiotic stage (e.g., Balsamo \& Todaro 2002; Nkem et al. 2006; Rivas Jr. et al. 2019).

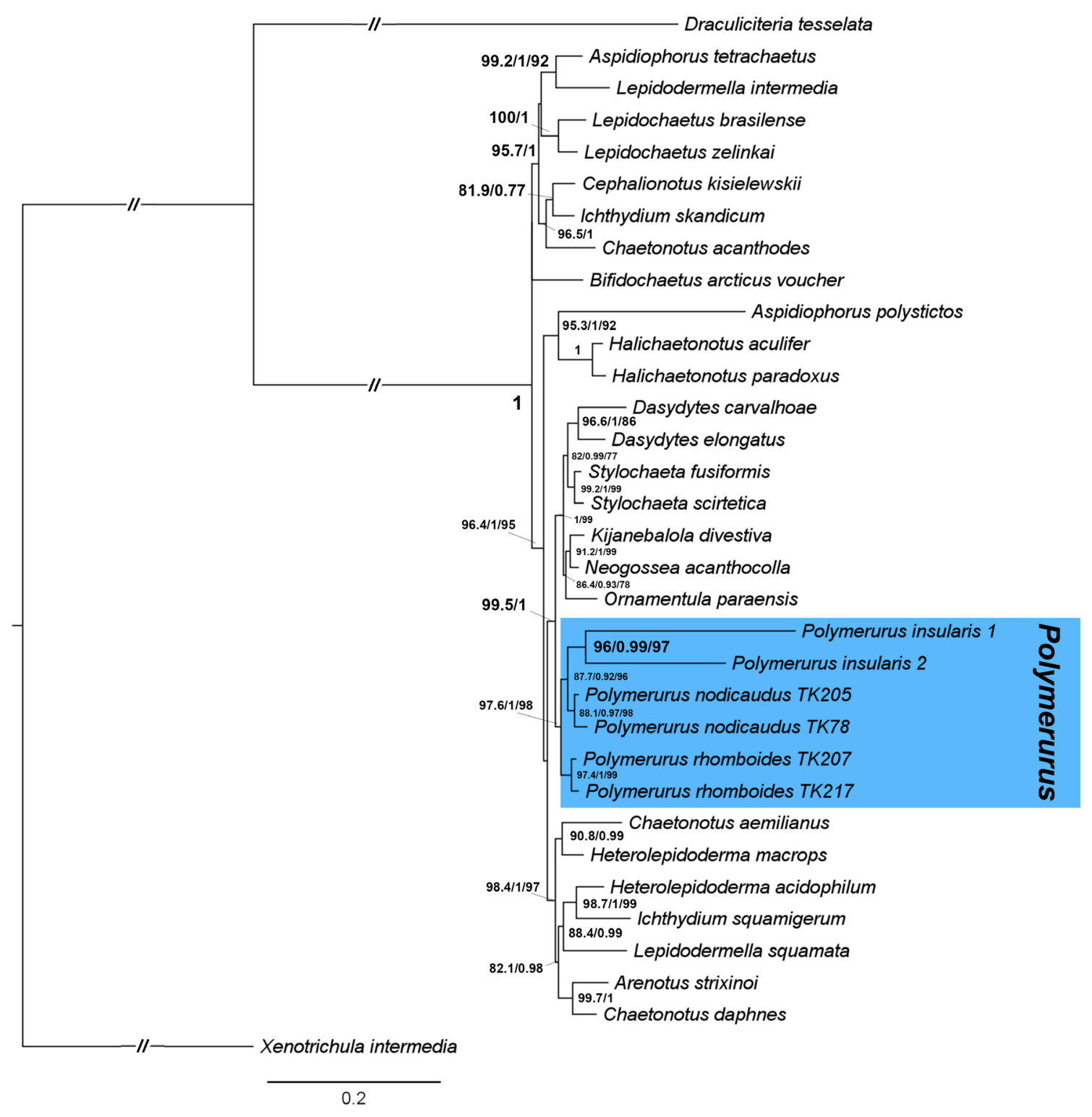

Fig. 9. Maximum Likelihood tree based on multigene approach with $18 \mathrm{~S}$ and $28 \mathrm{~S}$ sequences. Highlighted branches correspond to the Polymerurus Remane, 1927 species sequences. Values on the branches correspond, respectively, to: SH-aLRT support (\%) / aBayes support / ultrafast bootstrap support (\%). 
Regarding freshwater meiofaunal organisms, Hochberg (2005) suggested that the presence of Gastrotricha in isolated water bodies may be facilitated by parthenogenetic reproduction (in some species), which allows a single individual to establish a population in a new habitat (Incagnone et al. 2015), as well as the eggs' high dispersal capacity through the wind. Conversely, several other studies point to birds as important dispersal vectors of limnic organisms such as copepods (Halse et al. 2000; Green \& Figuerola 2005; Frisch et al. 2007; Dimante-Deimantovica et al. 2018), cladocerans (Halse et al. 2000; Frisch et al. 2007; Dimante-Deimantovica et al. 2018) or limnic-terrestrial species, such as tardigrades (Mogle et al. 2018). In this scenario, birds that constantly move between two suitable habitats, e.g., a temporary pond and a stream, might transport Gastrotricha propagules attached to their feathers or feet, through epizoochory (Greek: epi, upon), or ingested, through endozoochory (Greek, endo, inside) (Incagnone et al. 2015).

The Fernando de Noronha archipelago, specifically, is well known as a stopping-point for many migratory birds (Silva e Silva \& Olmos 2006; Silva e Silva 2008; Ferreira et al. 2019). The islands are visited by approximately 75 species of birds (Silva e Silva \& Olmos 2006), from which at least 14 were effectively observed within the extension of the Xaréu Reservoir (Silva e Silva \& Olmos 2006; Ferreira et al. 2019). It is important to highlight that, besides a few endemic bird species, the majority of birds observed in Fernando de Noronha archipelago are migratory or stray seabirds knowingly capable of undertaking long migration routes and coming from several different areas, such as North America (five species), Central America (three species), South America (five species), Africa (three species), Europe (seven species) and the Artic Polar Circle (one species) (Silva e Silva \& Olmos 2006; Piacentini et al. 2015; Ferreira et al. 2019).

Aside from passive dispersal through other animals as external vectors, anthropic actions cannot be excluded as a dispersal factor allowing freshwater gastrotrichs to reach Fernando de Noronha archipelago. The archipelago has been visited by humans for more than 500 years, and, along with that, various exotic animals have been constantly introduced to this environment and may have acted as vectors for passive dispersal: reptiles such as the black-and-white tegu Salvator merianae (Duméril \& Bibron, 1839), house geckos Hemidactylus mabouia (Moreau De Jonnès, 1818), mammals as the Rock Cavy Kerodon rupestris (Wied-Neuwied, 1820) and two species of amphibians, the Venezuela Snouted Treefrog Scinax x-signatus (Spix, 1824) and the Jimi's toad Rhinella jimi (Stevaux, 2002) (Santos 2011).

Within Chaetonotidae, the taxon Polymerurus can be considered an exception, as it is a strictly freshwater and a highly supported monophyletic group (Kånneby et al. 2013; Kolicka et al. 2020). Thus, in order to further investigate the evolutionary origins and phylogenetic relationships of Polymerurus insularis sp. nov. it is imperative to verify the existence of coastal specimens of the new species. In case such specimens are found, comparing them with the island specimens would contribute to the understanding of how and when P. insularis has reached the Fernando de Noronha Archipelago. Given the aforementioned condition of some descriptions of Gastrotricha and the overall resemblance of $P$. nodicaudus with $P$. insularis, it is not possible to discard that some representatives of $P$. insularis might have been described as $P$. nodicaudus.

\section{New species definition and pseudocryptism within Gastrotricha}

The definition of a new species can be especially challenging when the study of systematics and phylogeny are still emergent, as in the case within Gastrotricha. The morphological heterogeneity among gastrotrichs, in particular among the genus Polymerurus, had been almost fully undercovered due to the questionable cosmopolitan distribution of $P$. nodicaudus and $P$. rhomboides (see discussion below).

It is noteworthy that many species descriptions of gastrotrichs remain unstable for a series of reasons: i) the fragility of the specimens and the extensive morphological diversity among groups (Balsamo 
et al. 2008; Garraffoni et al. 2019b); ii) many descriptions date from decades/years ago and are brief and too generic (Garraffoni \& Melchior 2015; Kieneke \& Nikoukar 2017); iii) the use of rudimentary optical equipment for visualizing the specimens leading to schematic drawings that are too simplified and poorly illustrated; iv) the majority of the species do not have type series deposited in a zoological museum (Garraffoni et al. 2019b); v) the lack of a standardized method for the description of new species causing great disparity between species descriptions of the same genus from distinct authors (Visvesvara 1963; Kisielewski 1979, 1991; Balsamo et al. 2008; Grilli et al. 2010; Kånneby 2011).

Currently, such scenario raises important taxonomic problems, since, whenever scientists must consult past descriptions for a new study, they are often unable to discriminate among different species. It is very likely that overlooked morphological characters (or briefly mentioned and not effectively characterized features) might have impaired the identification of new species and/or species delimitation within Polymerurus (also in other taxa). This phenomenon of lumping distinct species into a single type can either create artificially cosmopolitan morphospecies (Klautau et al. 1999) or represent complexes of cryptic or pseudo-cryptic species.

Cryptic species are the morphotypes recognized as morphologically identical although genetically distinct (Lundholm et al. 2012). The definition and identification of cosmopolitan gastrotrichs became increasingly common in the past, however, reports of cryptic species, even though appearing few times, may lead to questioning the real cosmopolitanism of some Gastrotricha (Todaro et al. 1996; Leasi \& Todaro 2009; Kieneke et al. 2012; Kieneke \& Nikoukar 2017). On the other hand, when representatives of different populations (sympatric or allopatric) that were a priori recognized as morphologically very similar become independent species after the evidence of new characteristics, it is said that pseudocryptism has occurred (Bickford et al. 2007). Oftentimes, the acknowledgment of such characteristics is possible due to the improvement of the research methods and/or technologies that allow a more detailed analysis of those species' morphological structures (Saéz \& Lozano 2005; Lundholm et al. 2012, Kawauchi \& Giribet 2014).

Regarding Gastrotricha, even though the actual term pseudocryptism was never mentioned, it is possible that a few studies have detected this phenomenon before (e.g., Schwank 1990; Garraffoni \& Melchior 2015; Kieneke \& Nikoukar 2017). In this sense, Schwank (1990) revealed the existence of several new species, especially in South America and Africa, by reconsidering the status of some identifications presented in taxonomic surveys that happened in the early $20^{\text {th }}$ century (e.g., Daday 1905). Another example of pseudocryptism in Gastrotricha emerged from successive confocal analyses of the musculature of Xenotrichula intermedia Remane, 1934, a classic example of a widely distributed gastrotrich. Leasi \& Todaro (2009) reported differences in the muscular architecture between specimens classically determined as Xenotrichula intermedia found in Italy, United States and Kuwait. More recently, Münter \& Kieneke (2017) described a new type of muscular architecture for representatives of that species in Germany, while Araújo et al. (in prep.) have found two other muscular arrangements in sympatric populations on the east coast of the United States.

In the present paper, we observe that the newly proposed species was rather similar to representatives of Polymerurus nodicaudus regarding overall morphology, size and general features of the cuticular armature, and the differences diagnosed between the two species were only detected through detailed analysis using varied techniques. The presence of a triangular scale at the rear dorsal trunk (Type 2 scales), for example, the small spineless scales (Type 4 scales) at the base of the furca and the morphological details of Type 1 scales were observed with the support of DIC and SEM microscopy. Specimens of Polymerurus nodicaudus have been widely reported around the world for Palearctic (Voigt 1901; Kisielewski 1999; Leasi et al. 2006; Kånneby 2011; Kieneke \& Hochberg 2012), Neotropical (Kisielewski 1991), Australian (Hochberg 2005) and Oriental (Saito 1937; Sharma \& Sharma 1990) 
regions; however, a minor fraction of those works employed a DIC equipped microscope (Hochberg 2005; Kånneby 2011), and almost none used SEM in order to further examine finer details of the specimens structure (Hochberg 2005). In that sense, it is reasonable to say that, without the use of integrative techniques together with a careful morphological analysis, Polymerurus insularis sp. nov. could have been easily confused with $P$. nodicaudus. In fact, the same could have happened to other specimens in the past, including species described by former studies that detected $P$. nodicaudus worldwide. A review of $P$. nodicaudus is therefore necessary to investigate the possible presence of pseudocryptism within the described representatives of this species.

\section{Acknowledgments}

This work was supported by Biota Program/Fundação de Amparo à Pesquisa do Estado de São Paulo (FAPESP: 2014/23856-0), Fundo de Apoio ao Ensino, à Pesquisa e à Extensão (FAEPEX, UNICAMP) and Coordenação de Aperfeiçoamento de Pessoal de Nível Superior (CAPES, 001). We express our gratitude to the staff of Laboratory of Electron Microscopy of the Biology Institute (Unicamp), to Felipe Toledo (University of Campinas, Brazil) for sampling the material, to Lucas Freitas (University of Campinas, Brazil) for advisement on the phylogenetic analyses and to Rick Hochberg (University of Massachusetts - Lowell, USA) for his constructive criticism and grammar edition. We are grateful to Małgorzata Kolicka and anonymous reviewer for their constructive criticism that greatly improved the first version of the manuscript.

\section{References}

Alvares C.A., Stape J.L., Sentelhas P.C., de Moraes G. L.J. \& Sparovek G. 2014. Köppen's climate classification map for Brazil. Meteorologische Zeitschrift 22: 11-728. https://doi.org/10.1127/0941-2948/2013/0507

Balsamo M. 1982. Three new gastrotrichs from a Tuscan-Emilian Apennine lake. Italian Journal of Zoology 49: 287-295. https://doi.org/10.1080/11250008209439402

Balsamo M. 1983. Gastrotrichi. In: Consiglio Nazionale delle Ricerche (eds) Guide per il Riconoscimento delle Specie animali delle Acque interne italiane: 1-92. Consiglio Nazionale delle Ricerche, Verona.

Balsamo M. \& Todaro M.A. 2002. Gastrotricha. In: Rundle S.D., Robertson A.L. \& Schmid-Araya J.M. (eds) Freshwater Meiofauna: Biology and Ecology: 45-61. Backhuys Publishers, Leiden.

Balsamo M., Fregni E. \& Tongiorgi P. 1994. Marine and freshwater Gastrotricha from the Island of Montecristo (Tuscan Archipelago, Italy), with the description of new species. Italian Journal of Zoology 61: 217-227. https://doi.org/10.1080/11250009409355889

Balsamo M., d'Hondt J.-L., Kisielewski J. \& Pierboni L. 2008. Global diversity of gastrotrichs (Gastrotricha) in fresh waters. Hydrobiologia 595: 85-91.

https://doi.org/10.1007/978-1-4020-8259-7_10

Balsamo M., d'Hondt J.-L., Pierboni L. \& Grilli P. 2009. Taxonomic and nomenclatural notes on freshwater Gastrotricha. Zootaxa 2158: 1-19. https://doi.org/10.11646/zootaxa.2158.1.1

Balsamo M., Grilli P., Guidi L. \& d'Hondt J.-L. 2014. Gastrotricha - Biology, Ecology and Systematics. Families Dasydytidae, Dichaeturidae, Neogosseidae, Proichthydiidae. Backhuys Publishers and Margraf Publishers, Weikersheim.

Balsamo M., d'Hondt J.-L., Kisielewski J., Todaro M., Tongiorgi P., Guidi L., Grilli P. \& de Jong Y. 2015. Fauna Europaea: Gastrotricha. Biodiversity Data Journal 3: e5800.

https://doi.org/10.3897/BDJ.3.e5800 
MAGPALI L. et al., New species of Gastrotricha from an oceanic island

Balsamo M., Artois T., Smith J.P., Todaro M.A., Guidi L., Leander B.S. \& Van Steenkiste N.W. 2020. The curious and neglected soft-bodied meiofauna: Rouphozoa (Gastrotricha and Platyhelminthes). Hydrobiologia 847: 2613-2644. https://doi.org/10.1007/s10750-020-04287-x

Bickford D., Lohman D.J., Sodhi N.S., Ng P.K.L., Meier R., Winker K. \& Das I. 2007. Cryptic species as a window on diversity and conservation. Trends in Ecology \& Evolution 22: 148-155.

https://doi.org/10.1016/j.tree.2006.11.004

Bilton D., Freeland J. \& Okamura B. 2001. Dispersal in freshwater invertebrates. Annual Review of Ecology and Systematics 32: 159-181. https://doi.org/10.1146/annurev.ecolsys.32.081501.114016

Boeckner M.J., Sharma J. \& Proctor H.C. 2009. Revisiting the meiofauna paradox: dispersal and colonization of nematodes and other meiofaunal organisms in low- and high-energy environments. Hydrobiologia 624: 91-106. https://doi.org/10.1007/s10750-008-9669-5

Bohonak A.J. \& Jenkins D.G. 2003. Ecological and evolutionary significance of dispersal by freshwater invertebrates. Ecology Letters 6: 783-796. https://doi.org/10.1046/j.1461-0248.2003.00486.x

Bosco I., Lourenço A.P., Guidi L., Balsamo M., Hochberg R. \& Garraffoni A.R.S. 2020. Integrative description of a new species of Acanthodasys Remane, 1927 (Gastrotricha, Macrodasyida, Thaumastodermatidae) based on four distinct morphological techniques and molecular data. Zoologischer Anzeiger 286: 31-42. https://doi.org/10.1016/j.jcz.2020.03.003

Brunson R.B. 1950. An introduction to the taxonomy of the Gastrotricha with a study of eighteen species from Michigan. Transactions of the American Microscopical Society 69: 325-352.

https://doi.org/10.2307/3223127

Cerca J., Purschke G. \& Struck T.H. 2018. Marine connectivity dynamics: clarifying cosmopolitan distributions of marine interstitial invertebrates and the meiofauna paradox. Marine Biology 165: 123. https://doi.org/10.1007/s00227-018-3383-2

Cordani U.G., Ullbrich M.N.C., Onoe A.T. \& Vinasco-Vallejo C.J. 2004. Novas determinações de idade pelos métodos K-Ar e Ar-Ar para o arquipélago de Fernando de Noronha. Revista da Faculdade de Ciências, Universidade Eduardo Mondlade 1: 167-178.

Coughlan N.E., Kelly T.C., Davenport J. \& Jansen M.A. 2017. Up, up and away: bird-mediated ectozoochorous dispersal between aquatic environments. Freshwater Biology 62: 631-648.

https://doi.org/10.1111/fwb.12894

Daday E.V. 1905. Untersuchungen über die Süsswasser-Mikrofauna Paraguays. Zoologica 18: 1-375.

Dimante-Deimantovica I., Walseng B., Chertoprud E. \& Novichkova A. 2018. New and previously known species of Copepoda and Cladocera (Crustacea) from Svalbard, Norway - who are they and where do they come from? Fauna norvegica 38: 18-29. https://doi.org/10.5324/fn.v38i0.2502

Ferreira E.A., de Castro R., Fernandes R. \& Whittaker A. 2019. Two Palearctic herons on Fernando de Noronha, Brazil. Bulletin of the British Ornithologists Club 139 (2): 160-163.

https://doi.org/10.25226/bboc.v139i2.2019.a8

Fregni E., Balsamo M. \& Tongiorgi P. 1998. Interstitial gastrotrichs from lotic Italian fresh waters. Hydrobiologia 368: 175-187. https://doi.org/10.1023/A:1003250217483

Frisch D., Green A.J. \& Figuerola J. 2007. High dispersal capacity of a broad spectrum of aquatic invertebrates via waterbirds. Aquatic Sciences 69: 568-574. https://doi.org/10.1007/s00027-007-0915-0

Garraffoni A.R.S. \& Melchior M.P. 2015. New species and new records of freshwater Heterolepidoderma (Gastrotricha: Chaetonotidae) from Brazil with an identification key to the genus. Zootaxa 4057 (4): 551-568. https://doi.org/10.11646/zootaxa.4057.4.5 
Garraffoni A.R.S, Araújo T.Q., Lourenço A.P., Guidi L. \& Balsamo M. 2017. A new genus and new species of freshwater Chaetonotidae (Gastrotricha: Chaetonotida) from Brazil with phylogenetic position inferred from nuclear and mitochondrial DNA sequences. Systematics and Biodiversity 15: 49-62. https://doi.org/10.1080/14772000.2016.1214189

Garraffoni A.R.S., Araújo T.Q., Lourenço A.P., Guidi L. \& Balsamo M. 2019a. Integrative taxonomy of a new Redudasys species (Gastrotricha: Macrodasyida) sheds light on the invasion of freshwater habitats by macrodasyids. Scientific Reports 9: 2067. https://doi.org/10.1038/s41598-018-38033-0

Garraffoni A.R.S, Kieneke A., Kolicka M., Corgosinho P.H., Prado J., Nihei S.S. \& Freitas A.V. 2019b. ICZN Declaration 45: a remedy for the nomenclatural and typification dilemma regarding soft-bodied meiofaunal organisms? Marine Biodiversity 49: 2199-2207.

https://doi.org/10.1007/s12526-019-00983-7

Giere O. 2009. Meiobenthology. The Microscopic Motile Fauna of Aquatic Sediments. Springer, Berlin und Heidelberg.

Green A.J. \& Figuerola, J. 2005. Recent advances in the study of long-distance dispersal of aquatic invertebrates via birds. Diversity and Distributions 11: 149-156.

https://doi.org/10.1111/j.1366-9516.2005.00147.x

Grilli P., d'Hondt J.-L. \& Balsamo M. 2008. Contribution à la connaissance des Gastrotriches dulcicoles du département de la Gironde. Bulletin de la Société linnéenne de Bordeaux 36: 171-179.

Grilli P., Kristensen R.M. \& Balsamo M. 2010. Contribution to the knowledge of freshwater Gastrotricha from Denmark. Steenstrupia 32 (1): 79-92.

Grosso L.E. \& Drahg F. 1986. Gastrotricos dulceacuícolas de la provincia de Tucumán III. Acta Zoologica Lilloana 38: 139-149.

Halse S.A., Shiel R.J., Storey A.W., Edward D.H.D., Lansbury I., Cale D.J. \& Harvey M.S. 2000. Aquatic invertebrates and waterbirds of wetlands and rivers of the southern Carnarvon Basin, Western Australia. Records of the Western Australian Museum 61: 217-265.

https://doi.org/10.18195/issn.0313-122x.61.2000.217-265

Higgins R.P. \& Thiel H. 1988. Introduction to the Study of Meiofauna. Smithsonian Institution Press, Washington, DC.

Hochberg R. 2005. First record of Polymerurus (Gastrotricha, Chaetonotida) from Australia with the description of a new species from Queensland and of cuticular ultrastructure in $P$. nodicaudus. Invertebrate Biology 124: 119-130. https://doi.org/10.1111/j.1744-7410.2005.00014.x

Hochberg R. \& Litvaitis M.K. 2000. Hexamethyldisilazane for scanning electron microscopy of Gastrotricha. Biotechnic \& Histochemistry 75: 41-44. https://doi.org/10.3109/10520290009047984

Hummon W.D., Balsamo M. \& Todaro M.A. 1992. Italian marine Gastrotricha: I. Six new and one redescribed species of Chaetonotida. Italian Journal of Zoology 59 (4): 499-516.

https://doi.org/10.1080/11250009209386711

ICZN (International Commission on Zoological Nomenclature) 2017. Declaration 45 - Addition of Recommendations to Article 73 and of the term "specimen, preserved" to the Glossary. The Bulletin of Zoological Nomenclature 73 (2-4): 96-97. https://doi.org/10.21805/bzn.v73i2.a2

Incagnone G., Marrone F., Barone R., Robba L. \& Naselli-Flores L. 2015. How do freshwater organisms cross the "dry ocean"? A review on passive dispersal and colonization processes with a special focus on temporary ponds. Hydrobiologia 750: 103-123. https://doi.org/10.1007/s10750-014-2110-3 
MAGPALI L. et al., New species of Gastrotricha from an oceanic island

Kånneby T. 2011. New species and new records of freshwater Chaetonotida (Gastrotricha) from Sweden. Zootaxa 3115: 29-55. https://doi.org/10.11646/zootaxa.3115.1.3

Kånneby T. 2016. Phylum Gastrotricha. In: Thorp J.H. \& Rogers D.C. (eds) Key to Nearctic Fauna: Thorp and Covich's Freshwater Invertebrates: 115-130. Elsevier, Amsterdam.

Kånneby T. \& Hochberg R. 2015. Phylum Gastrotricha. In: Thorp J.H. \& Rogers D.C. (eds) Key to Nearctic Fauna: Thorp and Covich's Freshwater Invertebrates: 211-223. Elsevier, London.

Kånneby T. \& Kirk J.J. 2017. A new species of Redudasys (Gastrotricha: Macrodasyida: Redudasyidae) from the United States. Proceedings of the Biological Society of Washington 130: 128-139.

https://doi.org/10.2988/17-00006

Kånneby T. \& Todaro M.A. 2015. The phylogenetic position of Neogosseidae (Gastrotricha: Chaetonotida) and the origin of planktonic Gastrotricha. Organisms Diversity \& Evolution 15: 459-469. https://doi.org/10.1007/s13127-015-0223-9

Kånneby T., Todaro M.A. \& Jondelius U. 2012. A phylogenetic approach to species delimitation in freshwater Gastrotricha from Sweden. Hydrobiologia 683: 185-202.

https://doi.org/10.1007/s10750-011-0956-1

Kånneby T., Todaro M.A. \& Jondelius U. 2013. Phylogeny of Chaetonotidae and other Paucitubulatina (Gastrotricha: Chaetonotida) and the colonization of aquatic ecosystems. Zoologica Scripta 42: 88-105. https://doi.org/10.1111/j.1463-6409.2012.00558.x

Katoh K., Rozewicki J. \& Yamada K.D. 2019. MAFFT online service: multiple sequence alignment, interactive sequence choice and visualization. Briefings in Bioinformatics 20: 1160-1166.

https://doi.org/10.1093/bib/bbx108

Kawauchi G.Y. \& Giribet G. 2014. Sipunculus nudus Linnaeus, 1766 (Sipuncula): cosmopolitan or a group of pseudo-cryptic species? An integrated molecular and morphological approach. Marine Ecology 35: 478-491. https://doi.org/10.1111/maec.12104

Kieneke A. \& Hochberg R. 2012. Ultrastructural observations of the protonephridia of Polymerurus nodicaudus (Gastrotricha: Paucitubulatina). Acta Zoologica 93: 115-124.

https://doi.org/10.1111/j.1463-6395.2010.00494.x

Kieneke A. \& Nikoukar H. 2017. Integrative morphological and molecular investigation of Turbanella hyalina Schultze, 1853 (Gastrotricha: Macrodasyida), including a redescription of the species. Zoologischer Anzeiger 267: 168-186. https://doi.org/10.1016/j.jcz.2017.03.005

Kieneke A. \& Schmidt-Rhaesa A. 2015. Gastrotricha. In: Schmidt-Rhaesa A. (ed.) Handbook of Zoology 3. Gastrotricha and Gnathifera: 1-134. De Gruyter, Berlin, Boston.

Kieneke A., Martínez-Arbizu P.M. \& Fontaneto D. 2012. Spatially structured populations with a low level of cryptic diversity in European marine Gastrotricha. Molecular Ecology 21: 1239-1254.

https://doi.org/10.1111/j.1365-294X.2011.05421.x

Kisielewski J. 1979. New and insufficiently known freshwater Gastrotricha from Poland. Annales Zoologici 34: 415-435.

Kisielewski J. 1981. Gastrotricha from Raised and Transitional Peat Bogs in Poland. Monografie Fauny Polski 11, Panstwowe Wydawnictwo Naukowe, Warsaw, Mazowieckie województwo.

Kisielewski J. 1987. Two new interesting genera of Gastrotricha (Macrodasyida and Chaetonotida) from the Brazilian freshwater psammon. Hydrobiologia 153: 23-30. https://doi.org/10.1007/BF00005502

Kisielewski J. 1991. Inland-water Gastrotricha from Brazil. Annales Zoologici 43: 1-168. 
Kisielewski J. 1999. A preliminary study of the inland-water Gastrotricha of Israel. Israel Journal of Ecology and Evolution 45: 135-157. https://doi.org/10.1080/00212210.1999.10688984

Klautau M., Russo C.A., Lazoski C., Boury-Esnault N., Thorpe J.P. \& Solé-Cava A.M. 1999. Does cosmopolitanism result from over conservative systematics? A case study using the marine sponge Chondrilla nucula. Evolution 53: 1414-1422. https://doi.org/10.1111/j.1558-5646.1999.tb05406.x

Kolicka M., Dabert M., Dabert J., Kånneby T. \& Kisielewski J. 2016. Bifidochaetus, a new Arctic genus of freshwater Chaetonotida (Gastrotricha) from Spitsbergen revealed by an integrative taxonomic approach. Invertebrate Systematics 30: 398-419. https://doi.org/10.1071/IS16001

Kolicka M., Dabert M., Olszanowski Z. \& Dabert J. 2020. Sweet or salty? The origin of freshwater gastrotrichs (Gastrotricha, Chaetonotida) revealed by molecular phylogenetic analysis. Cladistics 36: 458-480. https://doi.org/10.1111/cla.12424

Larsson A. 2014. AliView: a fast and lightweight alignment viewer and editor for large datasets. Bioinformatics 30: 3276-3278. https://doi.org/10.1093/bioinformatics/btu531

Leasi F. \& Todaro M.A. 2009. Meiofaunal cryptic species revealed by confocal microscopy: the case of Xenotrichula intermedia (Gastrotricha). Marine Biology 156: 1335-1346.

https://doi.org/10.1007/s00227-009-1175-4

Leasi F., Rothe B.H., Schmidt-Rhaesa A. \& Todaro M.A. 2006. The musculature of three species of gastrotrichs surveyed with confocal laser scanning microscopy (CLSM). Acta Zoologica 87: 171-180. https://doi.org/10.1111/j.1463-6395.2006.00230.x

Lee J.M. \& Chang C.Y. 2000. Freshwater chaetonotid gastrotrichs in Korea. Animal Systematics, Evolution and Diversity 16 (1): 87-104.

Lundholm N., Bates S.S., Baugh K.A., Bill B.D., Connell L.B., Léger C. \& Trainer V.L. 2012. Cryptic and pseudo-cryptic diversity in diatoms - with descriptions of Pseudo-nitzschia hasleana sp. nov. and P. fryxelliana sp. nov. Journal of Phycology 48: 436-454.

https://doi.org/10.1111/j.1529-8817.2012.01132.x

Marques F.A., Souza R.A.S., de Souza J.E.S., Lima J.F.W.F. \& Souza-Júnior V.S.de 2014. Caracterização de vertissolos da ilha de Fernando de Noronha, Pernambuco. Revista Brasileira de Ciência do Solo 38: 1051-1065. https://doi.org/10.1590/S0100-06832014000400002

Martin L.V. 1990. Further observations on Gastrotrichs in Surrey and a provisional British list. Microscopy 36: 415-425.

Mogle M.J., Kimball S.A., Miller W.R. \& McKown R.D. 2018. Evidence of avian-mediated long distance dispersal in American tardigrades. PeerJ 6: e5035. https://doi.org/10.7717/peerj.5035

Münter L. \& Kieneke A. 2017. Novel myo-anatomical insights to the Xenotrichula intermedia species complex (Gastrotricha: Paucitubulatina): implications for a pan-European species and reconsideration of muscle homology among Paucitubulatina. Proceedings of the Biological Society of Washington 130: 166-186. https://doi.org/10.2988/17-00013

Nesteruk T. 2004. Benthic and epiphytic fauna of Gastrotricha in littoral of mesotrophic lake in ŁęcznaWłodawa Lakeland, Poland. Fragmenta Faunistica 47: 7-33.

https://doi.org/10.3161/00159301FF2004.47.1.001

Nkem J.N., Wall D.H., Virginia R.A., Barrett J.E., Broos E.J., Porazinska D.L. \& Adams B.J. 2006. Wind dispersal of soil invertebrates in the McMurdo Dry Valleys, Antarctica. Polar Biology 29: 346352. https://doi.org/10.1007/s00300-005-0061-x 
MAGPALI L. et al., New species of Gastrotricha from an oceanic island

Packard C.E. 1956. Studies on the Gastrotricha with especial reference to Polymerurus rhomboides Stokes in Virginia. Virginia Journal of Science 7: 293.

Packard C.E. 1959. Polymerurus nodicaudus Voigt from Ashland, Virginia. Turtox News 37: 156.

Piacentini V. de Q., Aleixo A., Agne C.E., Mauricio G.N., Pacheco J.F., Bravo G.A., Brito G.R.R., Naka L.N., Olmos F., Posso S., Silveira L.F., Betini G.S., Carrano E., Franz I., Lees A.C., Lima L.M., Pioli D., Schunck F., do Amaral F.R., Bencke G.A., Cohn-Haft M., Figueiredo L.F.A., Straube F.C. \& Cesari E. 2015. Annotated checklist of the birds of Brazil by the Brazilian Ornithological Records Committee. Revista Brasileira de Ornitologia 23: 91-298. https://doi.org/10.1007/BF03544294

Rao G.C. \& Clausen C. 1970. Planodasys marginalis gen. et sp. nov. and Planodasyidae fam. nov. (Gastotricha Magrodasyoidea). Sarsia 42: 73-82. https://doi.org/10.1080/00364827.1970.10411164

Remane A. 1927. Beiträge zur Systematik der Süsswassergastrotrichen. Zoologische Jahrbücher Abteilung für Systematik Oekologie und Geographie der Tiere 53: 269-320.

Rivas Jr. J.A., Schröder T., Gill T.E., Wallace R.L. \& Walsh E.J. 2019. Anemochory of diapausing stages of microinvertebrates in North American drylands. Freshwater Biology 64: 1303-1314.

https://doi.org/10.1111/fwb.13306

Roszczak R. 1969. Brzuchorzęski (Gastrotricha) środkowej Wielkopolski. Poznańskie Towarzystwo Przyjaciół Nauk. Wydziat matematyczno-przyrodniczy. Prace Komisji Biologicznej 32 (6): 1-92.

Ruttner-Kolisko A. 1955. Rheomorpha neiswestnovae und Marinellina flagellata, zwei phylogenetisch interessante Wurmtypen aus dem Süsswasserpsammon. Österreichische Zoologische Zeitschrift 6: 5569.

Sáez A.G. \& Lozano E. 2005. Body doubles. Nature 433 (7022): 111. https://doi.org/10.1038/433111a

Saito I. 1937. Neue und bekannte Gastrotrichen der Umgebung von Hiroshima (Japan). Journal of Science of the Hiroshima University 5: 245-265.

Santos J.T. 2011. História natural de Rhinella jimi (Anura, Bufonidae): uma espécie invasora em Fernando de Noronha. Master's degree thesis, Universidade Estadual de Campinas, Brazil.

Schwank P. 1990. Gastrotricha. In: Schwoerbel J. \& Zwick P. (eds) Süsswasserfauna von Mitteleuropa, Band 3. Gastrotricha und Nemertini: 1-252. Gustav Fischer Verlag, Stuttgart, Jena, New York.

Schwank P. \& Kånneby T. 2014. Contribution to the freshwater gastrotrich fauna of wetland areas of southwestern Ontario (Canada) with redescriptions of seven species and a check-list for North America. Zootaxa 3811: 463-490. https://doi.org/10.11646/zootaxa.3811.4.3

Sharma B.K. \& Sharma S. 1990. On some freshwater Gastrotricha from north-eastern region, with remarks on Indian taxa. Records of the Zoological Survey of India 86: 211-215.

Silva e Silva R. 2008. Aves de Fernando de Noronha. Avis Brasilis, São Paulo.

Silva e Silva R. \& Olmos F. 2006. Noteworthy bird records from Fernando de Noronha, northeastern Brazil. Revista Brasileira de Ornitologia 14: 470-474.

Available from http://www.revbrasilornitol.com.br/BJO/article/view/2726 [accessed 16 Mar. 2021].

Tavaré S. 1986. Some probabilistic and statistical problems in the analysis of DNA sequences. Lectures on Mathematics in the Life Sciences 17 (2): 57-86.

Teixeira W., Cordani U.G., Menor E.A., Teixeira M.G. \& Linsker R. 2003. Arquipélago de Fernando de Noronha, o paraíso do vulcão. Terra Virgem, São Paulo.

Todaro M.A. 2019. Freshwater. In: Todaro M.A. (ed.) Gastrotricha World Portal. Available from http://www.gastrotricha.unimore.it/freshwater.htm [accessed 15 Nov. 2019]. 
Todaro M.A., Fleeger J.W., Hu Y.P., Hrincevich A.W. \& Foltz D.W. 1996. Are meiofaunal species cosmopolitan? Morphological and molecular analysis of Xenotrichula intermedia (Gastrotricha: Chaetonotida). Marine Biology 125: 735-742. https://doi.org/10.1007/BF00349256

Todaro M.A., Kånneby T., Dal Zotto M. \& Jondelius U. 2011. Phylogeny of Thaumastodermatidae (Gastrotricha: Macrodasyida) inferred from nuclear and mitochondrial sequence data. PLOS ONE 6: e17892. https://doi.org/10.1371/journal.pone.0017892

Todaro M.A., Dal Zotto M., Jondelius U., Hochberg R., Hummon W.D., Kånneby T. \& Rocha C.E. 2012. Gastrotricha: a marine sister for a freshwater puzzle. PLoS ONE 7: e31740.

https://doi.org/10.1371/journal.pone.0031740

Todaro M.A., Dal Zotto M. \& Leasi F. 2015. An integrated morphological and molecular approach to the description and systematisation of a novel genus and species of Macrodasyida (Gastrotricha). PLoS ONE 10: e0130278. https://doi.org/10.1371/journal.pone.0130278

Todaro M.A., Sibaja-Cordero J.A., Segura-Bermúdez O.A., Coto-Delgado G., Goebel-Otárola N., Barquero D., Cullell-Delgado M. \& Dal Zotto M. 2019. An introduction to the study of Gastrotricha, with a taxonomic key to families and genera of the group. Diversity 11: 117-142.

https://doi.org/10.3390/d11070117

Trifinopoulos J., Nguyen L.T., von Haeseler A. \& Minh B.Q. 2016. W-IQ-TREE: a fast online phylogenetic tool for maximum likelihood analysis. Nucleic Acids Research 44: 232-235.

https://doi.org/10.1093/nar/gkw256

Vaidya G., Lohman D.J. \& Meier R. 2011. SequenceMatrix: concatenation software for the fast assembly of multi-gene datasets with character set and codon information. Cladistics 27: 171-180.

https://doi.org/10.1111/j.1096-0031.2010.00329.x

Visvesvara G. 1963. On some Gastrotricha from India with description of two new species. Journal of Natural History 6: 435-443. https://doi.org/10.1080/00222936308651379

Voigt M. 1901. Mittheilungen aus der biologischen Station zu Plön, Holstein. Über einige bisher unbekannte Susswasserorganismen. Zoological Anzeiger 24: 193-194.

WoRMS Editorial Board 2019. World Register of Marine Species.

Available from http://www.marinespecies.org/imis.php?module=dataset\&dasid=1447 [accessed 9 Aug. 2019].

Yang Z. 1994. Maximum likelihood phylogenetic estimation from DNA sequences with variable rates over sites: approximate methods. Journal of Molecular Evolution 39: 306-314.

https://doi.org/10.1007/BF00160154

Manuscript received: 22 August 2020

Manuscript accepted: 25 January 2021

Published on: 20 April 2021

Topic editor: Rudy Jocqué

Desk editor: Pepe Fernández

Printed versions of all papers are also deposited in the libraries of the institutes that are members of the EJT consortium: Muséum national d'histoire naturelle, Paris, France; Meise Botanic Garden, Belgium; Royal Museum for Central Africa, Tervuren, Belgium; Royal Belgian Institute of Natural Sciences, Brussels, Belgium; Natural History Museum of Denmark, Copenhagen, Denmark; Naturalis Biodiversity Center, Leiden, the Netherlands; Museo Nacional de Ciencias Naturales-CSIC, Madrid, Spain; Real 
MAGPALI L. et al., New species of Gastrotricha from an oceanic island

Jardín Botánico de Madrid CSIC, Spain; Zoological Research Museum Alexander Koenig, Bonn, Germany; National Museum, Prague, Czech Republic.

\section{Supplementary files}

Supp. file 1: List of valid species of the genus Polymerurus Remane, 1927 according to different versions in the literature. https://doi.org/10.5852/ejt.2021.746.1319.4025

Supp. file 2: Ultrafast bootstrap consensus tree based on multigene approach with $18 \mathrm{~S}$ and 28S sequences. Highlighted branches correspond to the Polymerurus Remane, 1927 species sequences. Values on the branches correspond to ultrafast bootstrap branch support.

https://doi.org/10.5852/ejt.2021.746.1319.4027 